\title{
Technology, Use and Reuse of Gold during the Middle Period: The Case of Casa Parroquial, Atacama Desert, Chile
}

\author{
María Teresa Plaza and Marcos Martinón-Torres
}

Published in Cambridge Archaeological Journal in 2021

DOI: https://doi.org/10.1017/S0959774321000123

\begin{abstract}
The life-histories of gold artefacts can provide rich insight into technology and culture, but so far the potential of this research approach has not been exploited in the south central Andes. Here we present the analysis of 34 gold and silver objects from the Middle Period cemetery of Casa Parroquial (San Pedro de Atacama, northern Chile), using pXRF, SEM-EDS, PIXE and digital microscopy. Chemical analyses detected variable compositions (2.4-73.1 per cent Ag and 0.23.4 per cent $\mathrm{Cu}$ ) suggesting that artisans used both native gold and artificial gold-silver-copper alloys. Based on their manufacturing techniques, quality and designs, we identify two working styles, one technically more 'careful' than the other. Given their elemental and technological variety, together with the lack of local production evidence, we propose that these artefacts were imported as finished objects from Tiwanaku or Cochabamba and northwest Argentina. However, we identify a series of objects that were modified or reshaped as they entered a new cultural context, revealing complex life-histories. Modifications used relatively simple mechanical means: punching, cutting and folding, most likely made in multi-craft contexts by non-metallurgists from San Pedro.
\end{abstract}

\section{Introduction}

The Middle Period (MP, A D 400-900) represents a dynamic moment when people, goods and ideas continuously moved between distant places within the south central Andes (SCA; Fig. 1). In this area comprising south Peru, eastern Bolivia, northwest Argentina (NWA) and northern Chile, the MP is characterized by the appearance of a variety of artefacts bearing an art style associated with Tiwanaku, thought to represent a shared religious iconography that developed in the Circumtiticaca area (Berenguer 1998; Korpisaari 2006). Although Tiwanaku colonies were set in some regions (e.g. Moquegua Valley), distant localities such as San Pedro de Atacama (SPA) in northern Chile (Fig. 1) stand out for the increment in quantity and variety of foreign artefacts, raw materials and status items related to the Tiwanaku phenomenon. Based on the presence of gold artefacts, pottery, snuffing trays and textiles with Tiwanaku iconography, for many years SPA was interpreted as a Tiwanaku colony (Barón 2004; Benavente et al. 1986; Tamblay 2004; Thomas et al. 1985). Today, the evidence indicates that the relationship with Tiwanaku was indirect, i.e. SPA was independent and autonomous, and its contact with Tiwanaku and other neighbouring regions such as NWA was articulated by dynamic trade routes mediated by communities from the southern Altiplano or other Tiwanaku centres such as Cochabamba (Berenguer et al. 1980; Castro et al. 2016; Dillehay \& Núñez 1988; 
Llagostera 2004; 2006; Salazar et al. 2014; Torres-Rouff et al. 2015; Uribe \& Agüero 2001; and more).

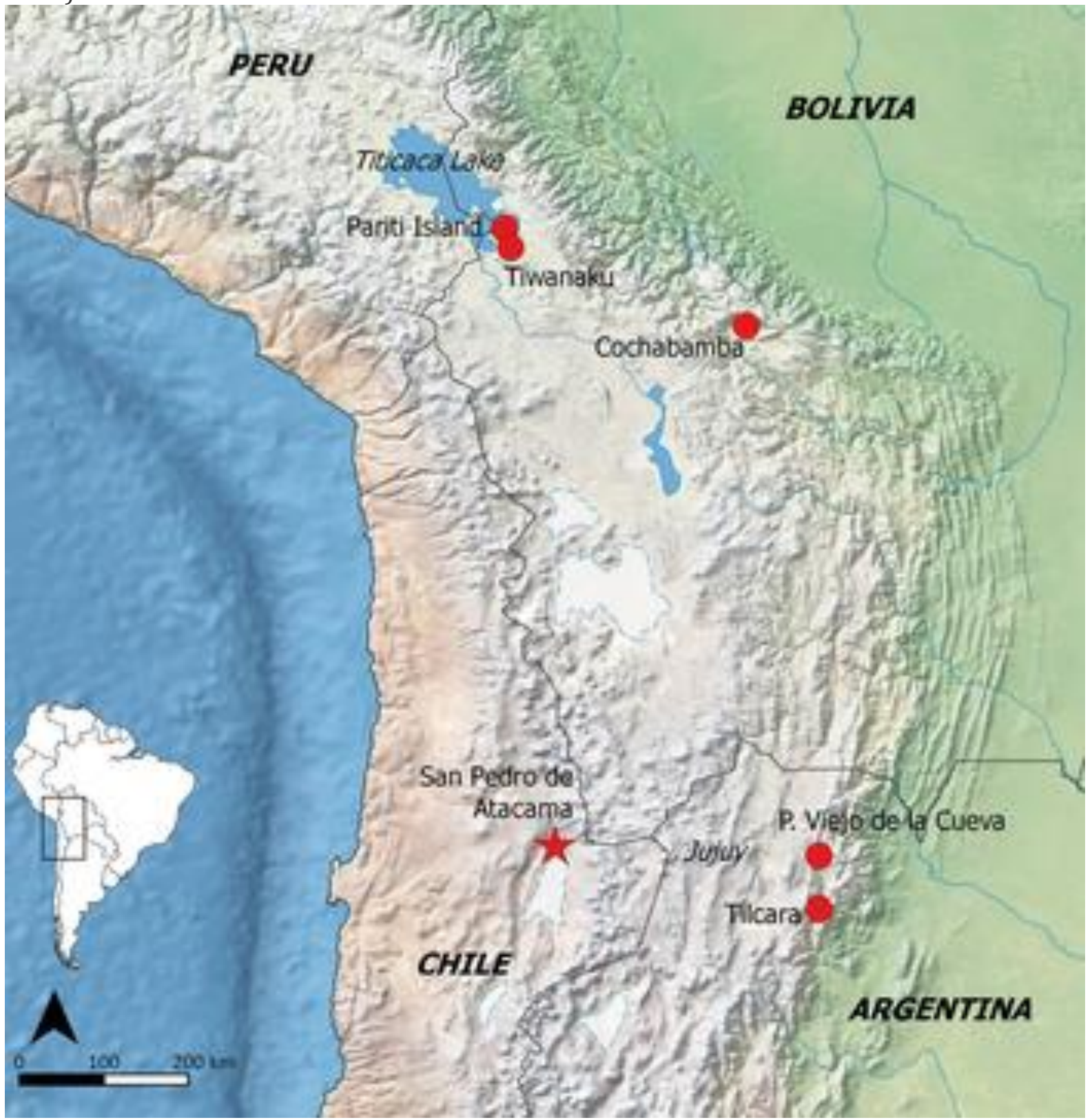

Figure 1. Map of the south central Andes showing the location of the sites mentioned in this paper. Casa Parroquial is located in San Pedro de Atacama.

Among the foreign goods reported in SPA, gold and silver offerings stand out in their relatively high concentration at this single locality. Gold and silver offerings in SPA include nearly 200 objects weighing approximately $2.5 \mathrm{~kg}$ in total. They are mainly small pendants, headbands, bracelets and pectorals, followed by some rings, headdresses, beads, bells and ritual goblets (keros and portrait-vessels), all items distributed in seven cemeteries.

Gold was the first metal to be used in the Andes. The earliest finds, dated around 21551936 B C , are nine tubular beads in Jiskairumoko, Peru (Aldenderfer et al. 2008); still, it was with the expansion of Chavin religious imagery during the Early Horizon (900 B C -0) that goldwork spread in the central and south central Andes (Lechtman 2014). According to Lechtman (2014), Chavin set the trend of using gold, and metals in general, deliberately to communicate and express religious, ideological and political power (González 2004a; González \& Vargas 1999; Lechtman 1991; 1993; Shimada et al. 2000). 
However, and despite their wide publicity in the present, gold ornaments are actually rare during the Middle Period; even at the site of Tiwanaku gold artefacts are uncommon (Korpisaari et al. 2011). At Tiwanaku itself, the greatest amount of gold ornaments is 15 offerings associated with three individuals in the Kalasasaya temple (Korpisaari 2006). Other important assemblages of the period include 23 gold objects found in a grave in Pariti island (Bennett 1936); the San Sebastian treasure with nearly 60 gold objects and almost 600 small pendants, also associated with one individual in Cochabamba (Money 1991); Burial 11 with 35 gold ornaments in La Isla de Tilcara, and Pueblo Viejo de la Cueva with nine objects, both in Jujuy, Argentina (Tarragó et al. 2010).

In general, gold finds are rare in the Altiplano and Jujuy, and they usually concentrate a significant number of artefacts in individual burials or offerings. In SPA, however, there are multiple individuals bearing gold (and silver) buried in different cemeteries at this single locality, which appears different from other contemporary contexts. Until now, it has been assumed that all the gold found in SPA was imported from Tiwanaku, resulting from attempts by local leaders at showing affiliation to the Tiwanaku sphere (Salazar et al. 2014; Tamblay 2004). However, the number of items and strategic location of SPA within the trade network suggest that the circulation of these items was more complex than expected, probably combining gold artefacts arriving from different areas (Stovel 2001; 2008).

So far, metallurgical studies in SPA have mainly focused on copper metallurgy (Cifuentes et al. 2018; Lechtman 1996; Lechtman \& Macfarlane 2005; 2006; Macfarlane \& Lechtman 2016; Maldonado et al. 2010; 2013; Salazar et al. 2011; 2014) and technological approaches to gold and silver have been absent. This paper presents the first results of a project focused on the gold and silver technology in SPA during the MP. We aim to contribute to both regional and local archaeologies by answering questions such as: a) how gold circulated within the SCA, and how precious metals connected SPA, Tiwanaku and other polities of the period; b) which artisanal practices are associated to this technology, described as a basic 'sheet technology'

(González 2004a); and c) how gold grave goods can reveal intra-community connections and allow us to explore their local meanings. Here, we study Casa Parroquial (CP), the cemetery with the second largest assemblage of gold offerings in SPA, using the elemental composition and manufacturing technology of gold and silver grave goods as a starting point to discuss social practices associated with the procurement, reshaping and offering of noble metals. Our discussion engages concepts that may be of relevance elsewhere, including the identification of individual artisans through reverse engineering of artefacts, the life-histories of objects, the value of gold, and multi-craft activities in heterarchical societies.

\section{Casa Parroquial}

Excavated in 1994 by Téllez and Murphy (2007), the site is located in the centre of the modern town of San Pedro de Atacama and was found during construction works made in the Parish House. The rescue excavation involved a very small area of $2 \times 3 \mathrm{~m}$, which revealed a section of a probably larger cemetery where 22 individuals were identified. Calibrated radiocarbon dates ( $2 \sigma$ ranges) from burial 6 (A D 899-1150) and burial 18 (A D 885-1101) place the site at the Middle Period, during the late Coyo Phase (A D 700-1000) (Stovel 2013, 378).

The stratigraphy of the site is complex, mainly due to a loose matrix composed of sand, coarse sediments and pebbles which made it very difficult to produce a clear record of the burials. The matrix was humid, which resulted in poor conservation of the organic material, and some areas were disturbed. Téllez and Murphy (2007), however, were able to identify burials of inverted cone shape, dug directly into the soil to a depth of 1.40-1.75 m with no markers such as posts or large rocks. The presence of a white layer of decomposed material surrounding some of the bodies and their undisturbed positions suggests to these authors that at least some individuals were wrapped in textiles before burial. Some of the features appear to be multiple burials, but the association between individuals was not always clear, except in the case of individuals 16a$16 \mathrm{~b}$ and $12-17$. The offerings were ascribed to specific individuals only when they were in 
direct association. A summary of the individuals and grave goods is given in Supplemental Table 1.

A total of 97 grave goods of different materials was recorded during the excavation, but some of them were in such poor condition that they did not survive thereafter. In particular, 15 sheets and discs of corroded silver were recorded (Téllez \& Murphy 2007), but only one fragment was found in the museum storage in 2016. Other findings comprise 36 gold objects, two copper artefacts, about 17 necklaces made of hundreds of copper mineral beads, fragments of nearly 16 pottery vessels, four bone tubes, six lithic objects, fragments of copper minerals, and a wooden tube.

Fourteen burials (64 per cent) contained metallic objects (Fig. 2). Of these 14, 10 burials (71 per cent) had gold offerings. Two burials contain only gold offerings (14 per cent), in six burials gold was combined with silver (43 per cent), and in two burials gold was combined with copper objects (14 per cent). The remaining four burials ( 29 per cent) contained only silver grave goods. Within the metallic assemblage of the site, the types of objects represented in gold are an axe $(\mathrm{n}=1)$, a wooden tube wrapped with a gold sheet $(\mathrm{n}=1)$, a portrait cup $(n=1)$, keros $(n=2)$, rings $(n=2)$, headdresses $(n=6)$, pendants $(n=7)$, sheets with perforations of varied shapes and forms $(n=9)$, and fragments of sheets $(n=6)$. In silver, the records identified discs $(n=5)$, conical bells $(n=2)$, chisels $(n=1)$ and many fragments. Finally, two copper axes were recovered. 


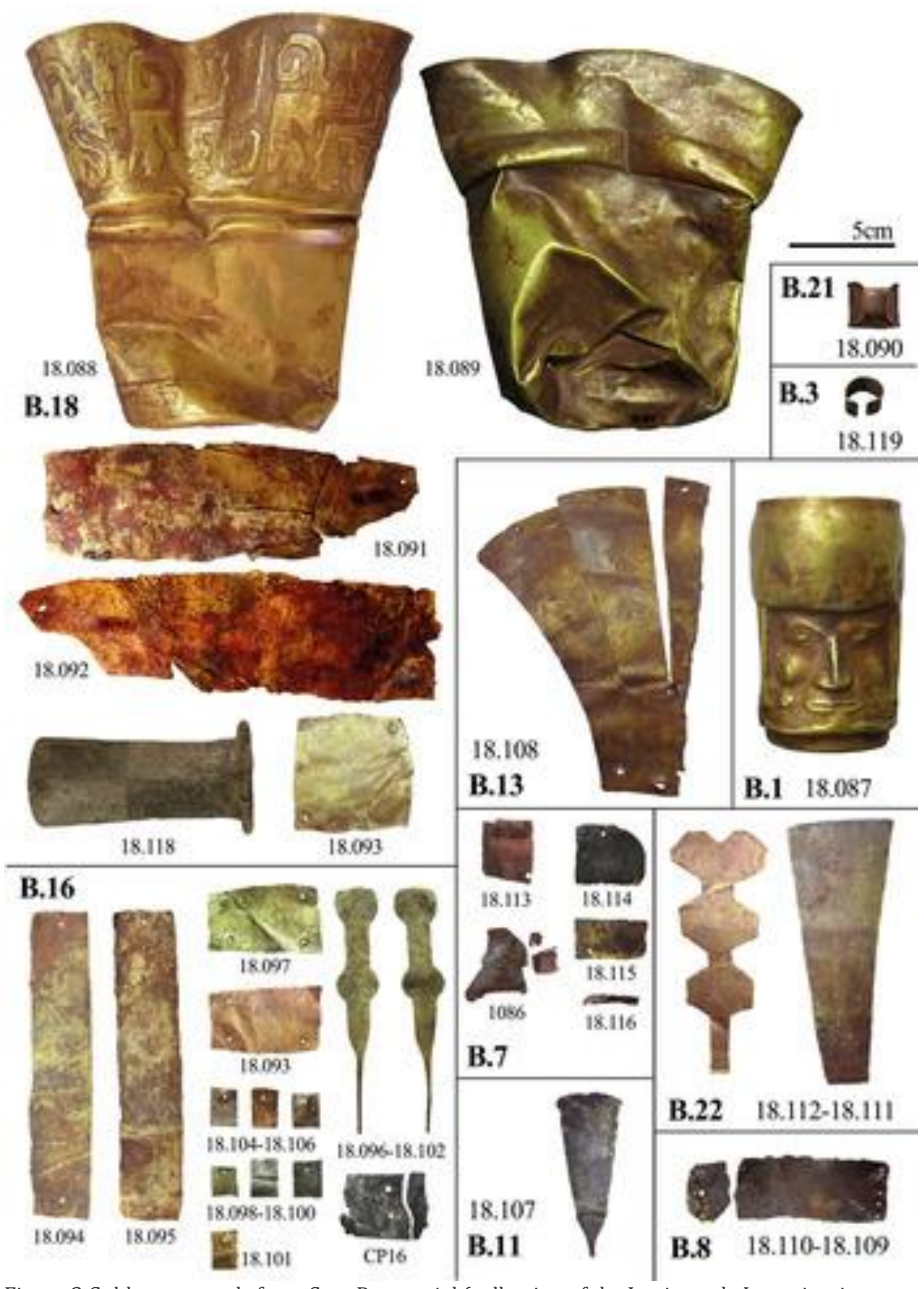

Figure 2 Gold grave goods from Casa Parroquial (collection of the Instituto de Investigaciones Arqueológicas y Museo R.P. Gustavo Le Paige s.j.). The variety in colours in objects from (a) B.16 (except CP16), 18.093 and 18.107; (b) B.22; and (c) 18.091/18.092 is due to different light conditions when photographs were taken, rather than reflecting actual differences (Photographs: M.T. Plaza.) 


\section{Methods}

Of 35 noble metal objects preserved, we analysed the 32 gold artefacts and a silver sheet recovered from the excavations and stored in the Museo Arqueológico R.P. Gustavo Le Paige from San Pedro de Atacama (935 g in total, excluding the gold axe, which weighs $203 \mathrm{~g}$ (A. Cifuentes, pers. comm. 2021)). Bulk chemical analyses of major elements ( $\mathrm{Au}-\mathrm{Ag}-\mathrm{Cu}$ ) were undertaken using Olympus Innov-X Delta Premium portable X-ray fluorescence spectrometers (pXRF) on unprepared surfaces. These pXRF instruments are equipped with a Si drift detector (SDD) and achieve a typical resolution of 145-150 eV FWHM for x-rays of $5.9 \mathrm{keV}$ (on a steel standard). Analyses were performed in the Alloy Plus mode using the so-called Beam 1 at $40 \mathrm{kV}$ with a $2 \mathrm{mil} \mathrm{Al}$ filter in the X-ray path, for $20 \mathrm{~s}$ live time, and quantified using fundamental parameters adjusted with empirical calibrations. The values given are averages of three readings per object, in percentage by weight. Although the manufacturer and set up are the same, two different instruments were used in this research (pXRF-2015 and pXRF-2016, after the year of analysis). Precision, accuracy and comparability within and between instruments were monitored using a series of certified reference materials. Results show a very good degree of correspondence between both instruments, allowing us to pool both datasets together (Supplemental Table 2).

To test further for minor ( $<1$ per cent) and trace elements $(<0.1$ per cent), samples of 11 objects were analysed at the AGLAE in Paris using particle-induced X-ray emission (PIXE). The setup used a $3 \mathrm{MeV}$ external proton beam of 30-50 $\mu \mathrm{m}, 3-6 \mathrm{nA}$ current and four Peltier-cooled SDD detectors to collect the X-rays emitted by the sample. Surface patinas were mechanically cleaned and the objects analysed once, using beam scanning areas of 500×500 $\mu \mathrm{m}$. Data normalization from different detectors was carried out using silver values, with the GUPIX program combined with the software TRAUPIXE.

Samples of 10 objects were mounted as polished metallographic sections and analysed using a Hitachi s-3400N scanning electron microscope with energy dispersive microscopy (SEM-EDS) at the UCL Institute of Archaeology. The instrument was operated at $20 \mathrm{kV}$ with counting times of $100 \mathrm{~s}$, a working distance of $10 \mathrm{~mm}$ and a process time of 5 . The same instrument was used to observe, under secondary and backscattered electron detectors, whole artefacts and unprepared samples placed directly in the SEM chamber under high vacuum. The SEM was set to $15-20 \mathrm{keV}$ and variable working distances were used. Finally, all objects were studied under naked eye and using a digital microscope (Dino-lite Edge), to register manufacturing traits. Our results also include the ICP-AES analysis of axe 18.118 by Salazar and colleagues (ㅁ11).

\section{Chemistry: results and discussion}

a. Bulk chemical composition

The bulk chemical composition of the 34 objects analysed shows a scattered distribution, where two broad groups are recognizable (Fig. 3): 91 per cent of the assemblage contains 61.9-94.2 per cent gold and 2.4-36.8 per cent silver; while 9 per cent of the assemblage has higher silver contents between 62.1 and 73.1 per cent, with 25.8-35.7 per cent gold (Table 1). The copper is low in all cases, ranging between 0.2 and 3.5 per cent. The high-silver group includes the socalled silver sheet (CP16), which turned out to be a gold-silver alloy instead of pure silver (26 per cent $\mathrm{Au}, 73$ per cent $\mathrm{Ag}$ and 1 per cent $\mathrm{Cu}$ ). To this picture one should add those fragments recorded as 'silver' during excavation but not preserved: it is not possible to ascertain whether these would have fallen in the silver-rich group or formed a separate group with higher silver levels. 


\section{D) C) B) A)}

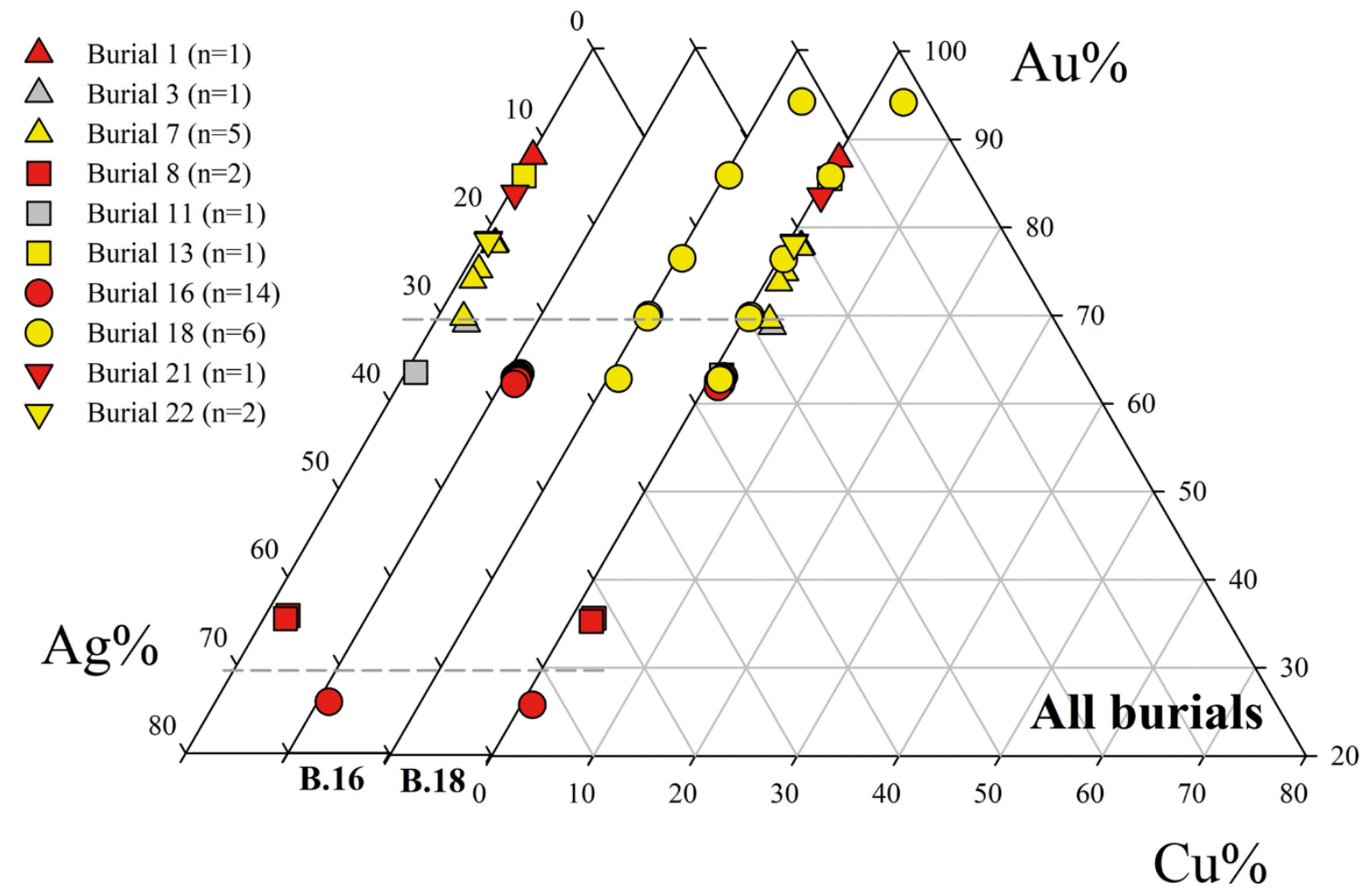

Figure 3. Gold-silver-copper ternary diagram presenting the bulk chemical composition of the 34 gold grave goods from Casa Parroquial, by pXRF, and one by ICP-AES (Salazar et al. 2011). (A) Diagram showing all burials; (B) only burial 18; (C) only burial 16; (D) all burials except 16 and 18.

Table 1. Chemical composition of 34 offerings from Casa Parroquial, by pXRF and ICP-AES. 


\begin{tabular}{|c|c|c|c|c|c|c|c|c|c|}
\hline No. & Object & Burial & $\begin{array}{c}\text { Museum } \\
\text { id }\end{array}$ & $\begin{array}{l}\text { Lab } \\
\text { id }\end{array}$ & $\begin{array}{c}\text { pXRF } \\
\text { instrument }\end{array}$ & $\mathrm{Cu}$ & $\mathrm{Au}$ & Ag & $\mathrm{Ag} /(\mathrm{Ag}+\mathrm{Au}) \%$ \\
\hline 1 & Portrait cup & 1 & 18.087 & popm141 & 2016 & 0.2 & 87.8 & 12.0 & 12.0 \\
\hline 2 & Ring & 3 & 18.119 & popm089 & 2016 & 3.2 & 68.8 & 28.0 & 28.9 \\
\hline 3 & Rectangular sheet & \multirow{5}{*}{7} & 1086 & popm002 & 2015 & 1.5 & 77.9 & 20.6 & 20.9 \\
\hline 4 & Rectangular sheet & & 18.113 & popm009 & 2015 & 1.5 & 77.8 & 20.8 & 21.1 \\
\hline 5 & Rectangular sheet & & 18.115 & popm008 & 2015 & 1.5 & 76.8 & 21.7 & 22.0 \\
\hline 6 & Irregular sheet & & 18.116 & popm003 & 2015 & 1.4 & 73.7 & 24.9 & 25.3 \\
\hline 7 & Square sheet & & 18.114 & popm011 & 2015 & 2.5 & 69.5 & 27.9 & 28.7 \\
\hline 8 & Rectangular sheet & \multirow{2}{*}{8} & 18.109 & popm001 & 2016 & 2.2 & 35.7 & 62.1 & 63.5 \\
\hline 9 & Pendant & & 18.110 & popm010 & 2016 & 2.2 & 35.3 & 62.6 & 63.9 \\
\hline 10 & Headdress & 11 & 18.107 & popm085 & 2016 & 1.0 & 63.3 & 35.8 & 36.1 \\
\hline 11 & Tripartite headdress & 13 & 18.108 & popm 087 & 2016 & 0.4 & 85.5 & 14.0 & 14.1 \\
\hline 12 & Headdress & \multirow{14}{*}{16} & 18.096 & popm082 & 2016 & 1.3 & 63.1 & 35.7 & 36.1 \\
\hline 13 & Headdress & & 18.102 & popm083 & 2016 & 1.3 & 63.1 & 35.7 & 36.1 \\
\hline 14 & Pendant & & 18.100 & popm075 & 2016 & 1.2 & 62.9 & 35.9 & 36.4 \\
\hline 15 & Pendant & & 18.098 & popm074 & 2016 & 1.2 & 62.8 & 35.9 & 36.4 \\
\hline 16 & Pendant & & 18.105 & popm047 & 2016 & 1.2 & 62.8 & 36.0 & 36.4 \\
\hline 17 & Pendant & & 18.099 & popm076 & 2016 & 1.1 & 62.8 & 36.2 & 36.6 \\
\hline 18 & Rectangular sheet & & 18.097 & popm077 & 2016 & 1.2 & 62.6 & 36.1 & 36.6 \\
\hline 19 & Band & & 18.094 & popm079 & 2016 & 1.3 & 62.5 & 36.2 & 36.7 \\
\hline 20 & Rectangular sheet & & 18.103 & popm078 & 2016 & 1.2 & 62.5 & 36.4 & 36.8 \\
\hline 21 & Pendant & & 18.101 & popm073 & 2016 & 1.0 & 62.6 & 36.5 & 36.8 \\
\hline 22 & Band & & 18.095 & popm080 & 2016 & 1.4 & 62.3 & 36.3 & 36.8 \\
\hline 23 & Pendant & & 18.104 & popm051 & 2016 & 1.2 & 62.3 & 36.5 & 36.9 \\
\hline 24 & Pendant & & 18.106 & popm050 & 2016 & 1.3 & 61.9 & 36.8 & 37.3 \\
\hline 25 & Irregular sheet & & C.P.16 & popm007 & 2015 & 1.1 & 25.8 & 73.1 & 73.9 \\
\hline 26 & Axe* & \multirow{6}{*}{18} & 18.118 & popm049 & ICP-2011 & 3.4 & 94.2 & 2.4 & 2.5 \\
\hline 27 & Kero & & 18.088 & popm140 & 2016 & 0.4 & 85.8 & 13.8 & 13.9 \\
\hline 28 & Kero & & 18.089 & popm139 & 2016 & 0.5 & 76.4 & 23.1 & 23.2 \\
\hline 29 & Headband & & 18.092 & popm018 & 2015 & 0.5 & 69.9 & 29.6 & 29.7 \\
\hline 30 & Headband & & 18.091 & popm017 & 2015 & 0.5 & 69.7 & 29.8 & 30.0 \\
\hline 31 & Square sheet & & 18.093 & popm081 & 2016 & 1.1 & 62.7 & 36.2 & 36.6 \\
\hline 32 & Ring & 21 & 18.090 & popm088 & 2016 & 0.6 & 83.6 & 15.9 & 16.0 \\
\hline 33 & Headdress & \multirow{2}{*}{22} & 18.112 & popm086 & 2016 & 0.6 & 78.3 & 21.1 & 21.2 \\
\hline 34 & Headdress & & 18.111 & popm084 & 2016 & 0.6 & 78.1 & 21.2 & 21.4 \\
\hline
\end{tabular}

Notes. Values are an average of three readings, and are normalized to a 100 weight per cent.

Results are organized by burials and gold content. *Axe analysed by ICP-AES by Salazar et al. 2011.

We calculated the $\mathrm{Ag} /(\mathrm{Ag}+\mathrm{Au})$ percentage ratio to facilitate comparisons. This ratio has been used in archaeometallurgical studies of $\mathrm{Au}-\mathrm{Ag}$-Cu alloys to estimate the hypothetical amount of silver naturally present in naturally argentiferous gold before it was alloyed with copper, based on the facts that alluvial gold generally has negligible amounts of copper ( $<1$ per cent), and assuming that all the silver in the gold was present as a natural impurity (Guerra \& Calligaro 2004; Hough et al. 2009; Martinón-Torres et al. 2007; 2012; Uribe \& MartinónTorres 2012). Bearing in mind that a) copper values in SPA assemblage are typically very low (up to 3.5 per cent) and b) the presence of silver objects at the site (Téllez \& Murphy 2007) suggests that silver could have been available for artificial alloys (and not only as a natural impurity in the gold), we use this ratio for a different purpose here: as a descriptive parameter to search for compositions that might denote either individual gold sources or possible alloying practices (see following section). The results in Figure 4a show that the resulting value is lower than 30 per cent for 47 per cent of the objects; 44 per cent display levels between 30 and 40 per cent; and 9 per cent of the assemblage has a higher value of over 60 per cent. Copper contents 
are very low, with 86 per cent of the objects containing levels up to 1.5 per cent, and only 15 per cent with 2.0-3.5 per cent copper levels ( $\underline{\text { Fig. } 4 \text { b) }}$.

A

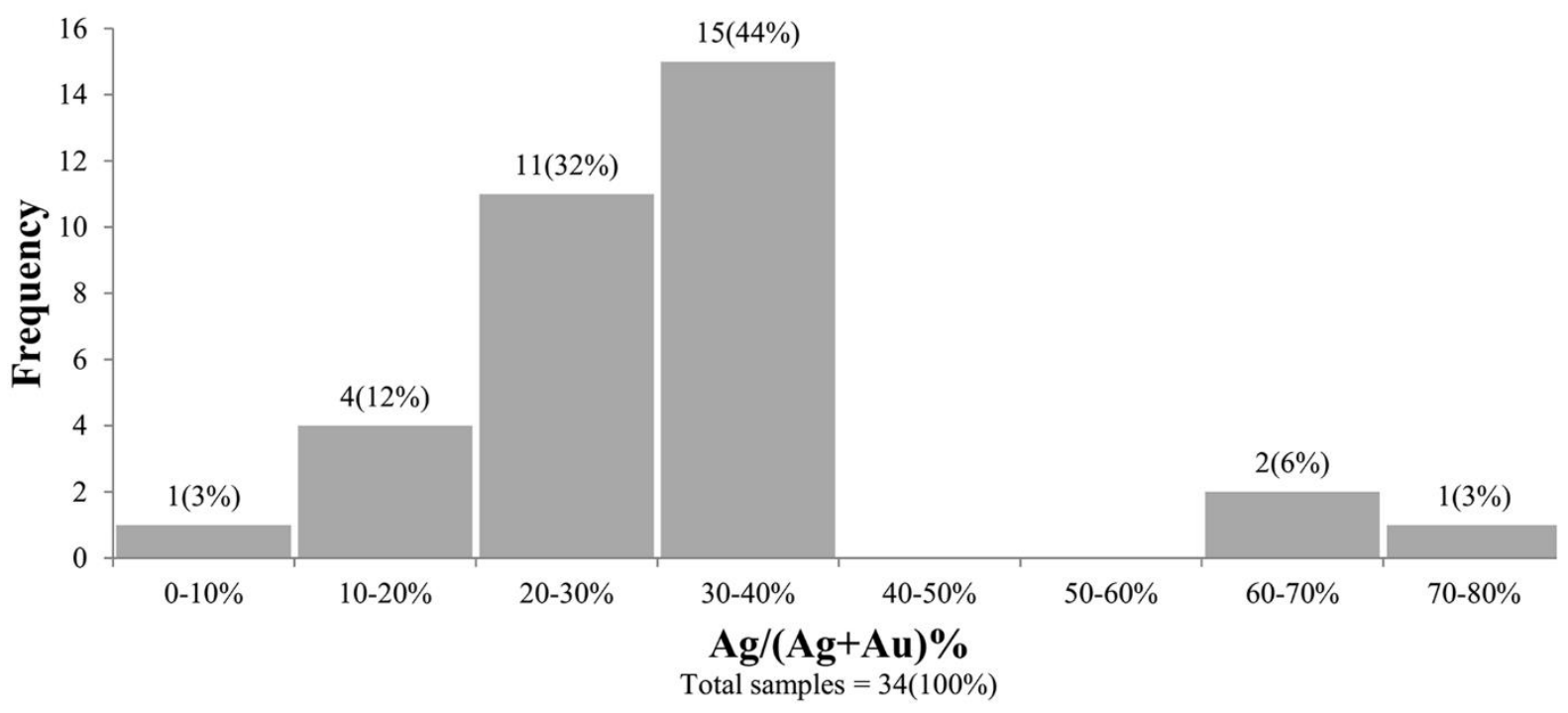

B

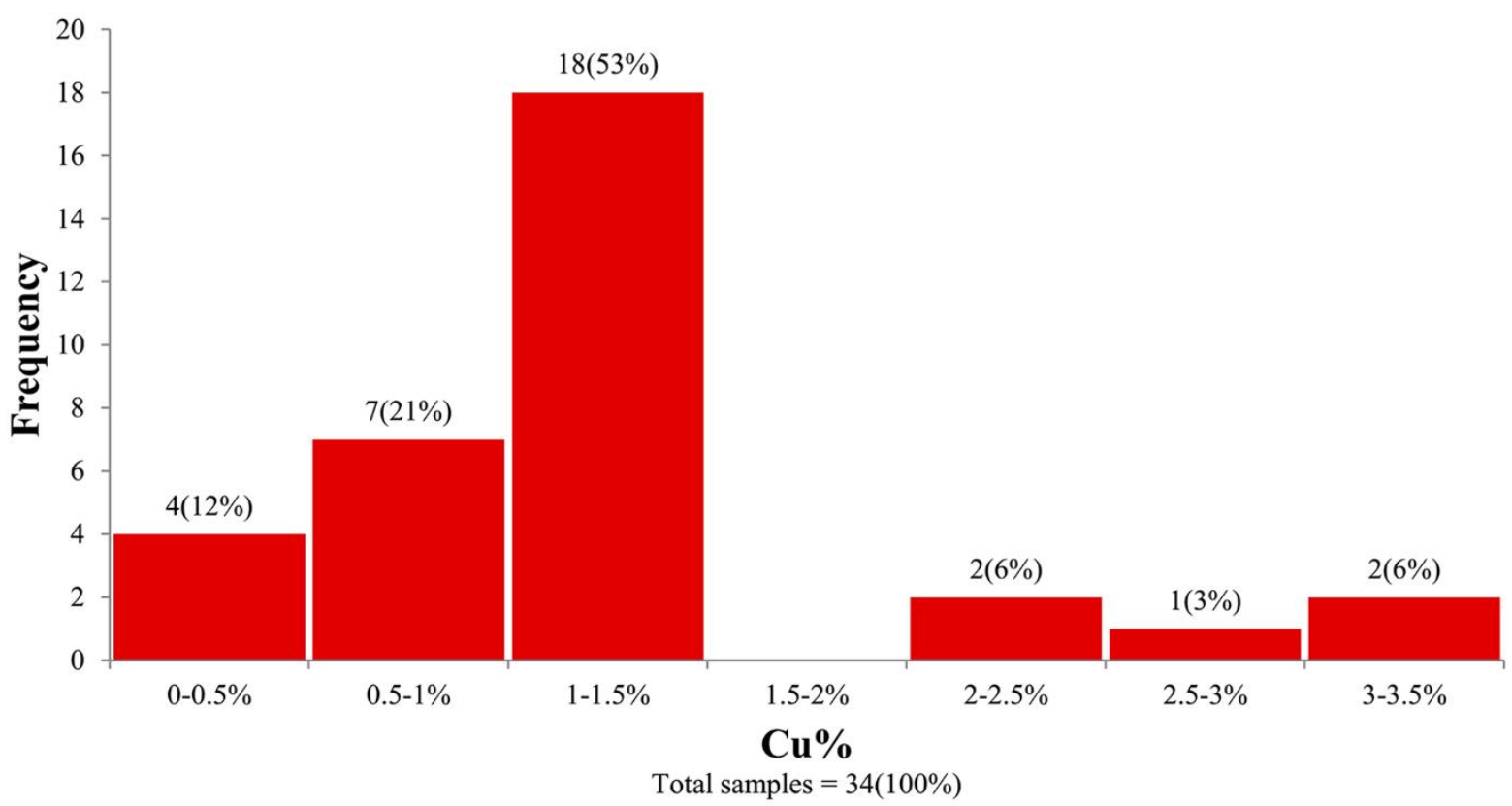

Figure 4. (A) Frequency distribution histogram of $\mathrm{Ag} /(\mathrm{Ag}+\mathrm{Au})$ percentage values of 34 objects from Casa Parroquial; (B) frequency distribution histogram of $\mathrm{Cu}$ per cent of 34 objects from Casa Parroquial.

PIXE results show that all the objects analysed contain zinc as a trace element, while titanium, gallium and nickel are scarce (2-3 cases, Supplemental Table 3). Meanwhile, under the SEM we identified minute iron-rich inclusions in the matrix of five objects $(18.091,18.092,18.113$, 18.115 and 18.116), and copper-rich inclusions in samples 18.109 and 18.110. Inclusions of complex composition containing copper, iron, tin, zinc or arsenic were identified in samples 18.092 and 18.110 as well.

Interestingly, some objects share very similar bulk compositions (Table 1). This is the case of 15 pendants and headdresses from burials 11,18 and 16 , which form a very tight compositional group with 1.0-1.4 per cent copper and 35.7-36.8 per cent silver. Other examples showing almost the exact same composition are sheets 1086 and 18.113 from burial 7 (1.5 per cent $\mathrm{Cu}$, 
21 per cent $\mathrm{Ag}$ ), pendants 18.109 and 18.110 from burial 8 ( 2 per cent $\mathrm{Cu}, 62$ per cent $\mathrm{Ag}$ ), headdresses 18.111 and 18.112 from burial 22 ( 1 per cent $\mathrm{Cu}, 21$ per cent $\mathrm{Ag}$ ); and the kero 18.088 from burial 18 with the headdress 18.108 from burial 13 (0.4 per cent $\mathrm{Cu}, 14$ per cent Ag). Headbands 18.091 and 18.092 from burial 18 share both bulk composition (0.5 per cent $\mathrm{Cu}, 30$ per cent $\mathrm{Ag}$ ) and trace elements (Fe, Zn, Ti: Table $2 \mathrm{a}$ ).

Table 2. Summary of artefacts sharing the same composition (a), manufacture traits $(b-c)$ and modified objects (d) from Casa Parroquial.

\begin{tabular}{|c|c|c|c|c|c|c|c|}
\hline 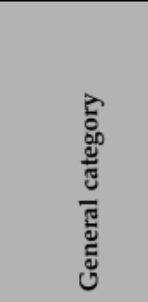 & 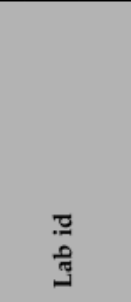 & 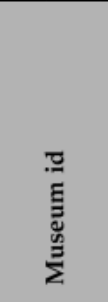 & 刭 & 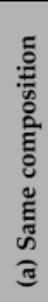 & 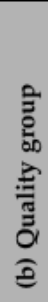 & 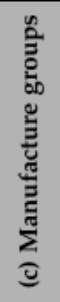 & 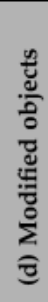 \\
\hline Port. vessel & popm141 & 18.087 & 1 & - & 2 & - & - \\
\hline Ring & popm089 & 18.119 & 3 & - & 1 & - & - \\
\hline Sheet & popm009 & 18.113 & \multirow{5}{*}{7} & 2 & - & - & - \\
\hline Sheet & popm011 & 18.114 & & - & - & - & - \\
\hline Sheet & popm008 & 18.115 & & - & - & - & - \\
\hline Sheet frag. & popm003 & 18.116 & & - & - & - & - \\
\hline Sheet & popm002 & 1086 & & 2 & - & - & - \\
\hline Band & popm001 & 18.109 & \multirow{2}{*}{8} & 3 & 1 & 1.2 & $x$ \\
\hline Pendant & popm010 & 18.110 & & 3 & 1 & 1.2 & $x$ \\
\hline Headdress & popm085 & 18.107 & 11 & 1 & 1 & - & - \\
\hline Headdress & popm087 & 18.108 & 13 & 5 & 2 & - & $\mathrm{x}$ \\
\hline Band & popm079 & 18.094 & \multirow{14}{*}{16} & 1 & 1 & 1.3 & $x$ \\
\hline Band & popm080 & 18.095 & & 1 & 1 & 1.3 & $x$ \\
\hline Headdress & popm083 & 18.102 & & 1 & 1 & - & - \\
\hline Headdress & popm082 & 18.096 & & 1 & 1 & - & - \\
\hline Pendant & popm077 & 18.097 & & 1 & 1 & 1.3 & $\mathrm{x}$ \\
\hline Pendant & popm078 & 18.103 & & 1 & 1 & 1.3 & $x$ \\
\hline Pendant & popm074 & 18.098 & & 1 & 1 & 1.3 & $x$ \\
\hline Pendant & popm076 & 18.099 & & 1 & 1 & 1.3 & $x$ \\
\hline Pendant & popm075 & 18.100 & & 1 & 1 & 1.3 & $x$ \\
\hline Pendant & popm 073 & 18.101 & & 1 & 1 & 1.3 & $x$ \\
\hline Pendant & popm051 & 18.104 & & 1 & 1 & 1.3 & $x$ \\
\hline Pendant & popm047 & 18.105 & & 1 & 1 & 1.3 & $x$ \\
\hline Pendant & popm050 & 18.106 & & 1 & 1 & 1.3 & $x$ \\
\hline Sheet frag. & popm007 & C.P.16 & & - & - & - & - \\
\hline Pendant & popm081 & 18.093 & \multirow{5}{*}{18} & 1 & 1 & 1.3 & $x$ \\
\hline Kero & popm140 & 18.088 & & 5 & 2 & - & - \\
\hline Kero & popm139 & 18.089 & & - & 2 & - & - \\
\hline Band & popm017 & 18.091 & & 6 & 1 & 1.1 & $\mathrm{x}$ \\
\hline Band & popm018 & 18.092 & & 6 & 1 & 1.1 & $x$ \\
\hline Ring & popm088 & 18.090 & 21 & - & 2 & - & - \\
\hline Headdress & popm084 & 18.111 & \multirow{2}{*}{22} & 4 & 2 & - & - \\
\hline Headdress & popm086 & 18.112 & & 4 & 2 & - & $x$ \\
\hline
\end{tabular}

When we look at the distribution of compositions within burials, we see different patterns ( $\underline{\text { Fig. }}$. 3). For example, in burials 7 and 18, object compositions appear scattered; while in burials 8,22 and 16 all the offerings plot together (except the high-silver object CP16 from burial 16). From burials 1, 3, 11, 13 and 21 we analysed only one metal object each.

b. Native gold and alloys 
Silver levels up to 30 per cent are consistent with silver content naturally present in alluvial gold deposits. Higher values are possible but very rare, hence pointing to artificial gold-silver alloys (Chapman et al. 2002; Guerra et al. 2019; Hough et al. 2009; Samusikov 2002; Spiridonov \& Yanakieva 2009). Near SPA there are gold and silver deposits, but they have not been chemically characterized. The records found to date are from other gold deposits from the central and south central Andes, which contain different amounts of silver. For example, very pure gold with silver up to 5-7 per cent is found in south Peru (Sandia and Carabaya region), in Bolivia (south Lipez, the Eastern Cordillera and Yani region) and in Jujuy, Argentina (Mina Eureka). Meanwhile, silver contents up to 10-14 per cent are recorded in San Pedro de Cachiyuyo (Atacama region, Chile), Vilander placer (south Lipez, Bolivia), Vetasmayo placer (south Peru), Ancash (north coast of Peru) and Rinconada (Jujuy). Finally, high silver levels are registered in Cerro Casale with up to 21 per cent Ag (Atacama region, Chile); in La Joya district in Bolivia with 30 per cent Ag; and in the alluvial deposits of the Tumbes River at the boundary between Peru and Ecuador with 26 per cent Ag (Alarcón \& Fornari 1994; Angiorama 2004; Hérail et al. 1990; 1999; Palacios et al. 2001; Petersen 1970; Ramos \& Fornari 1994). Considering the above, it is plausible that the objects from CP with silver levels up to 30 per cent may have been made of unalloyed native gold. Based on the variable $\mathrm{Ag} /(\mathrm{Ag}+\mathrm{Au})$ percentage ratios recorded, it is likely that different gold deposits are represented in the assemblage. Likewise, iron-rich inclusions were found in five objects with silver levels below 30 per cent. The presence of iron-rich minerals in gold is not unusual (Angiorama 2004; Guerra \& Calligaro 2004; McEwan \& Haeberli 2000). They are typically found in alluvial gold grains as remnants of the original primary deposits in which gold is usually associated with quartz, limonite, hematite and pyrite as host minerals (Boric et al. 1990, 68, 82, 94). However, upon melting of native gold, these mineral impurities tend to be separated by their lower density and immiscibility, forming slag or dross. Consequently, their presence in sheets 18.113, 18.115 and 18.116, and in headbands 18.091 and 18.092, all with silver levels up to 30 per cent, would suggest that the metal was not necessarily melted; possibly these sheets were shaped from gold grains applying cycles of cold-work and annealing.

For artefacts with over 30 per cent Ag, however, it is much more likely that we are dealing with artificial alloys (Angiorama 2004; Guerra et al. 2019; Lechtman 1978; Root 1949; Rovira 1994; Schlosser et al. 2009). Therefore, the presence of artefacts with both low and high silver suggests the possible presence of both naturally argentiferous gold and gold artificially alloyed with additional silver. We cannot rule out, however, that different types of native gold were melted or mixed together.

Regarding the copper content, it is widely accepted that native gold usually contains levels of copper below 1 per cent, commonly ranging between 0.1 and 0.8 per cent (Guerra \& Calligaro 2004; Hough et al. 2009; Schlosser et al. 2009; Spiridonov \& Yanakieva 2009; Townley et al. 2003). However, other authors report copper levels up to 2 per cent or even extraordinary cases of 6-8 per cent $\mathrm{Cu}$ in alluvial gold (Ogden 2000; Petersen 1970). Chemical analyses of samples from gold deposits in the central and south central Andes usually show copper levels as traces, i.e. <0.1 per cent (Alarcón \& Fornari 1994; Ramos \& Fornari 1994). Exceptions are primary deposits in Chile and placer deposits in Zaruma (boundary between Peru and Ecuador), which contain copper up to 0.7 per cent (Hérail et al. 1990; Palacios et al. 2001; Petersen 1970), or placers in the north coast of Peru (Pallasca and Ninamahua) containing copper levels up to 6-8 per cent, a very unusual composition for native gold (Petersen 1970).

Against this background, the copper levels for most of the artefacts analysed would seem consistent with natural impurities (cf. Guerra et al. 2019). Importantly, copper contents up to 5 per cent in gold alloys will not affect the colour or melting temperatures significantly (Schlosser et al. 2009, 416), and would thus not necessarily be noticeable for the user or producer of the object. Most probably, therefore, even the copper levels above 1 per cent in the assemblage are unintentional, indicating either the use of alluvial gold deposits with exceptionally high copper levels, or contamination with copper minerals during collection or 
while melting in crucibles previously used for copper (González 2003; Guerra \& Rehren 2009; Hauptmann \& Klein 2009).

PIXE results show zinc as the main impurity in the analysed objects. This element is also found in gold and silver objects from Salta and Jujuy (Argentina), together with iron and nickel (Angiorama 2001; González 2004a, 333). Unfortunately, published data of trace elements in gold or silver objects from the south central Andes for comparative use are extremely limited, with notable absences in Chile and Bolivia, making it premature to pinpoint specific geological sources.

\section{Technology: results and discussion}

a. Manufacturing techniques

All the objects in CP (89 per cent), except the three goblets and, probably, the axe (likely cast, although we could not examine it) were made of hammered sheets that were cut to shape. Hammering and cutting marks are visible on the surface of nearly 20 objects (57 per cent; Table 3); in two headbands ( 6 per cent) we also identified folding as a main forming technique. In eight cases (23 per cent) the presence of lines adjacent to cut edges suggests the use of guide lines drawn prior to the cut. Alternatively, the portrait-vessel and two keros ( 9 per cent) were modelled by 'raising', a technique whereby a metal sheet is hammered against a matrix, compressing the metal and raising the walls at the same time, achieving a 3D shape (see Carcedo et al. 2004, 164). As to finishing techniques, we registered 20 objects (57 per cent) with polished surfaces (one or two sides); and polished edges were identified in nine cases (26 per cent). Only four objects analysed were decorated: the three goblets and a ring. Embossing, chasing, chiselling and pointillism were used to decorate the goblets, while the ring was decorated with an attached appliqué that is missing. While conscious of the risks of value judgements, we can state that the vast majority of the objects are cursory and quite rudimentary in their manufacture and appearance, in the sense that they did not engage particularly complex techniques. Therefore, we find it useful to discriminate objects showing evidence of more sophisticated skills and/or careful manufacture from those displaying a more limited range and/or a more cursory approach to manufacture (Kuijpers $2015 ; \underline{2017}$; 2018).

Table 3. Summary of the manufacture techniques observe in the assemblage of Casa Parroquial $(\mathrm{n}=33)$. The forming, finishing and decoration techniques identified here are based on the presence/absence of marks present on the surfaces. The dimensions of the objects are given in Supplemental Table 4. 


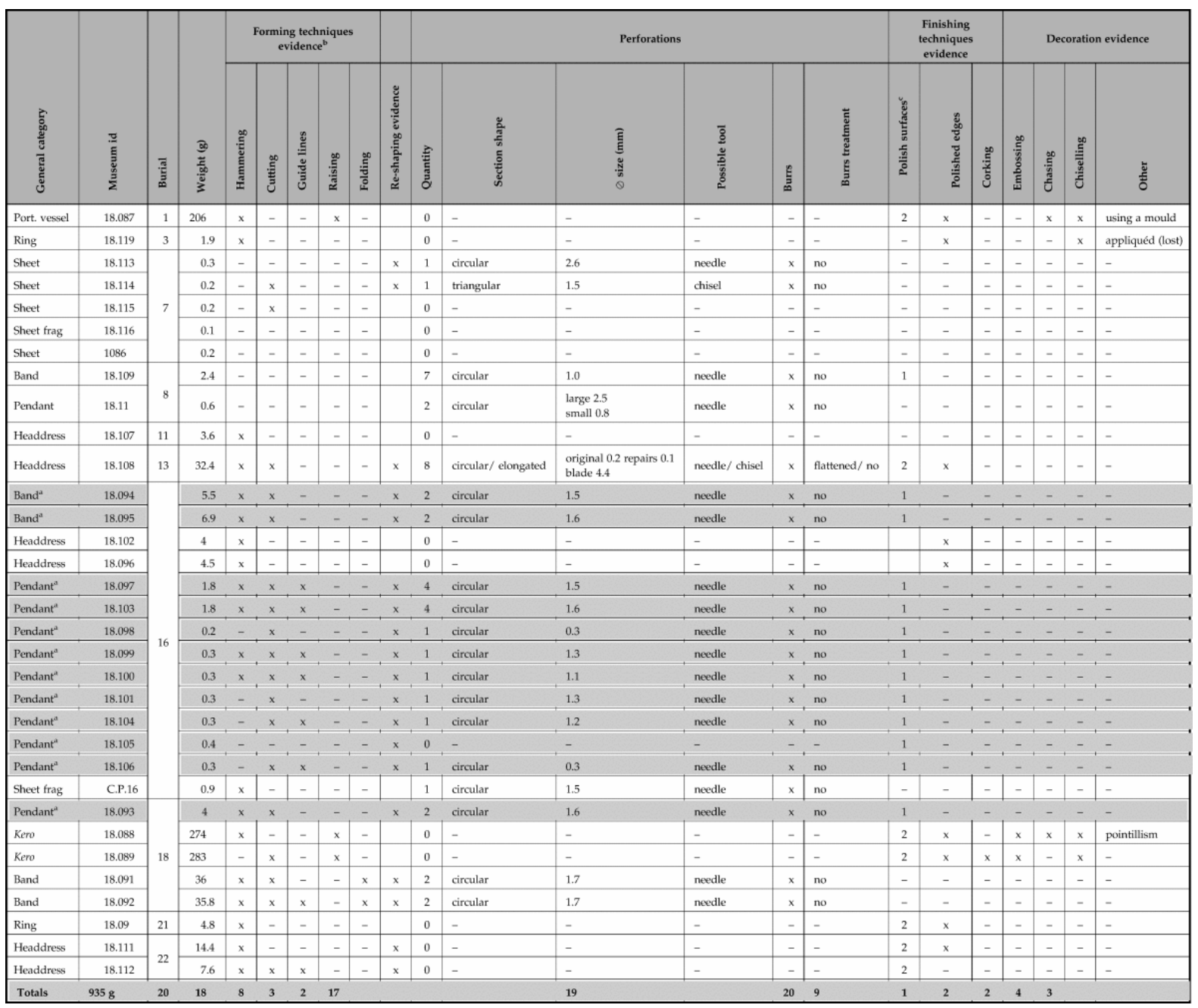

Notes. (a) Largest cluster of objects sharing the same manufacture techniques. (b) We register the presence/absence of visible forming techniques, finishing treatment and decoration technique marks. (c) 1 = objects with only one polished surface. 2 = objects with all their surfaces polish (both sides in two-dimensional sheets and the exterior in the case of the keros).

Based on manufacturing traits, we can cluster some objects together. The largest cluster comprises 12 objects that share many features (Table 3 ). These are seven rectangular pendants (18.098-18.101, 18.104-18.106), two rectangular sheets $(18.097,18.103)$, and two bands $(18.094,18.095)$ from burial 16; and a square sheet 18.093 from burial 18. The surface of the 12 objects is the same: rough on one side and smooth on the other, although there are not visible polishing marks. The edges were roughly cut and not polished, leaving the same fresh cutmarks on many objects (Fig. $5 \mathrm{a}-\mathrm{c}$ ); only a few of them have one or two worn edges, which may represent the original edges of the object or larger sheet from which these were cut. In six sheets we found possible guide lines, suggesting that the artisan drew the design before cutting

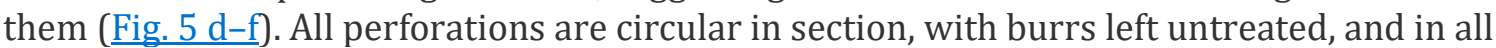
cases there is a long burr with the imprint of a point, suggesting the use of a pointy tool such as a needle (Fig. 5 i-j). Furthermore, they are similar in shape; e.g. sheets 18.097 and 18.103 could have been made by cutting a sheet like 18.093 in half; and the seven rectangular pendants appear to be part of a large and thin band cut into pieces (Fig. 2 B16, B18). 

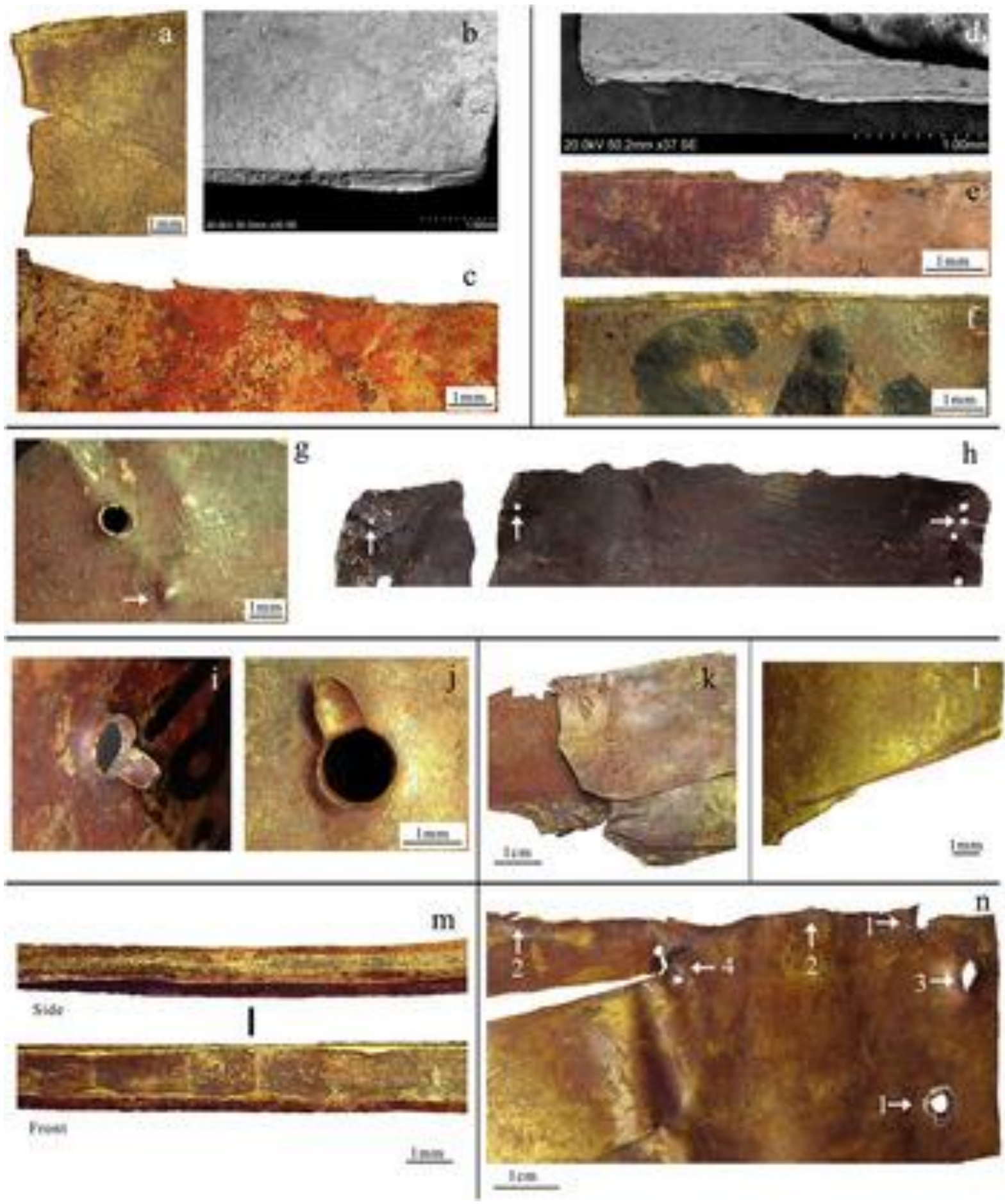

Figure 5. Details of manufacture traits. Fresh and unpolished edges in pendants (a)18.097; (b) 18.105; (c) 18.094; guide lines in pendants (d) 18.105; (e) 18.106; (f) 18.100; (g) attempts at perforation in pendant 18.109; (h) repair in 18.109-18.110; needle-type marks in (i) 18.105 and (j) 18.103; (k) folding evidence in headdress 18.091; (l) unpolished marks in 18.112; (m) hammering and polishing marks in headdress 18.102; (n) headdress 18.108 showing 1: flattened original perforations; 2: rough cuts; 3: untreated perforations; 4: repair. (Photographs: M.T. Plaza.)

Similar to the previous group, but without visible cutting marks, are sheets 18.107, 18.109 and 18.110 , characterized by uneven and worn edges. Sheets 18.109 and 18.110 appear to be parts of the same pendant that broke before it was buried. The presence of three similar aligned perforations linking both sheets suggests they may have been part of a repair to hold both parts 
together (Fig. $5 \mathrm{~h}$ ). We also found imprints on the surfaces, probably failed perforation attempts (Fig. 5 g). The circular perforations, the imprints and their similarity with other perforations of the assemblage suggest the use of a pointed tool, possibly a needle. The headbands 18.091and 18.092 show characteristic peculiarities: they were shaped by folding, hammering and cutting a larger gold sheet, leaving pronounced folds all over the surface (Fig. $5 \mathrm{k})$. Once the main shape was obtained, the ends were perforated with a needle. Burrs were not treated and in two cases the same perforation was punched twice. The technique in general is still unsophisticated. Headdresses 18.096 and 18.102 show a somewhat more careful manufacture, while both are identical in design and manufacturing techniques. They comprise an elongated sheet with a disc-shaped decoration at the centre and top end (Fig. 2 B16), and a thick and pointy appendix of rectangular section. Their edges are smooth and polished; long facets are visible on the pointy end, suggesting the use of a smooth tool (perhaps a stone) to round and polish the sides and edges (Fig. $5 \mathrm{~m}$ ). Surfaces, in contrast, were not polished.

An interesting case of artefacts clearly altered and reshaped are headdresses 18.108, 18.111 and 18.112. The headdress 18.108 is a well-made tripartite sheet, with polished surfaces and edges, comparable to others found in Copiapo (Chile) and northwest Argentina (see Fig. 8 b-c), although these have four rather than three appendices (González 2006, 252). The perforations at the base are circular and the burrs were flattened (Fig. $5 \mathrm{n} 1$ ). However, at some point in its life, this ornament was crudely cut, losing some of its appendices. The cuts are short, perpendicular, chiselling marks (Fig. $5 \mathrm{n} 2$ ). The same blade was used to perforate the base and the top of the appendices; these perforations were not treated (Fig. $5 \mathrm{n} 3$ ). Two small circular perforations were added as part of a repair to avoid losing the thinnest appendix (Fig. 5 n 4 ). Headdresses 18.111 and 18.112 present similar cases, albeit with more subtle modification. Both headdresses have polished surfaces. Now, 18.111 has a trapezoidal shape and its edges are even and polished, erasing all cutting marks. In turn, 18.112 has a complex shape: two hexagons at the centre and a heart shape at the top (Fig. 2 B22). The edges of this headdress are roughly cut and unpolished, leaving visible cutmarks at the borders (Fig. $5 \mathrm{l}$ ). The bottom edge of both ornaments seems straight but under the microscope it appears irregular and slightly bent, suggesting that the sheets were detached from a larger one by bending the metal until it broke (possibly another four-appendix headdress). When both headdresses are stacked together, they fit perfectly (Fig. 6 c). This, combined with the same elemental composition and texture of the surfaces, clearly shows that sheet 18.112 was once a trapezoidal sheet (like 18.111) that was subsequently reshaped, cutting out some sections of the metal to obtain a new design. We therefore have objects that were intentionally reshaped. Interestingly, the quality is very different between the original work and the modification: the former is careful and tidy, whereas the latter is relatively rough and, to our modern Western eye, careless, $\underline{1}$ with no finishing treatments to match the quality of the original work. This is a strong indication that the modifications would have taken place at different times of the objects' life-histories, revealing rather complex biographies where the final appearance of the object was the result of its production and alterations during use (see Sáenz Samper \& Martinón-Torres 2017 for other examples in Pre-Columbian goldwork). 

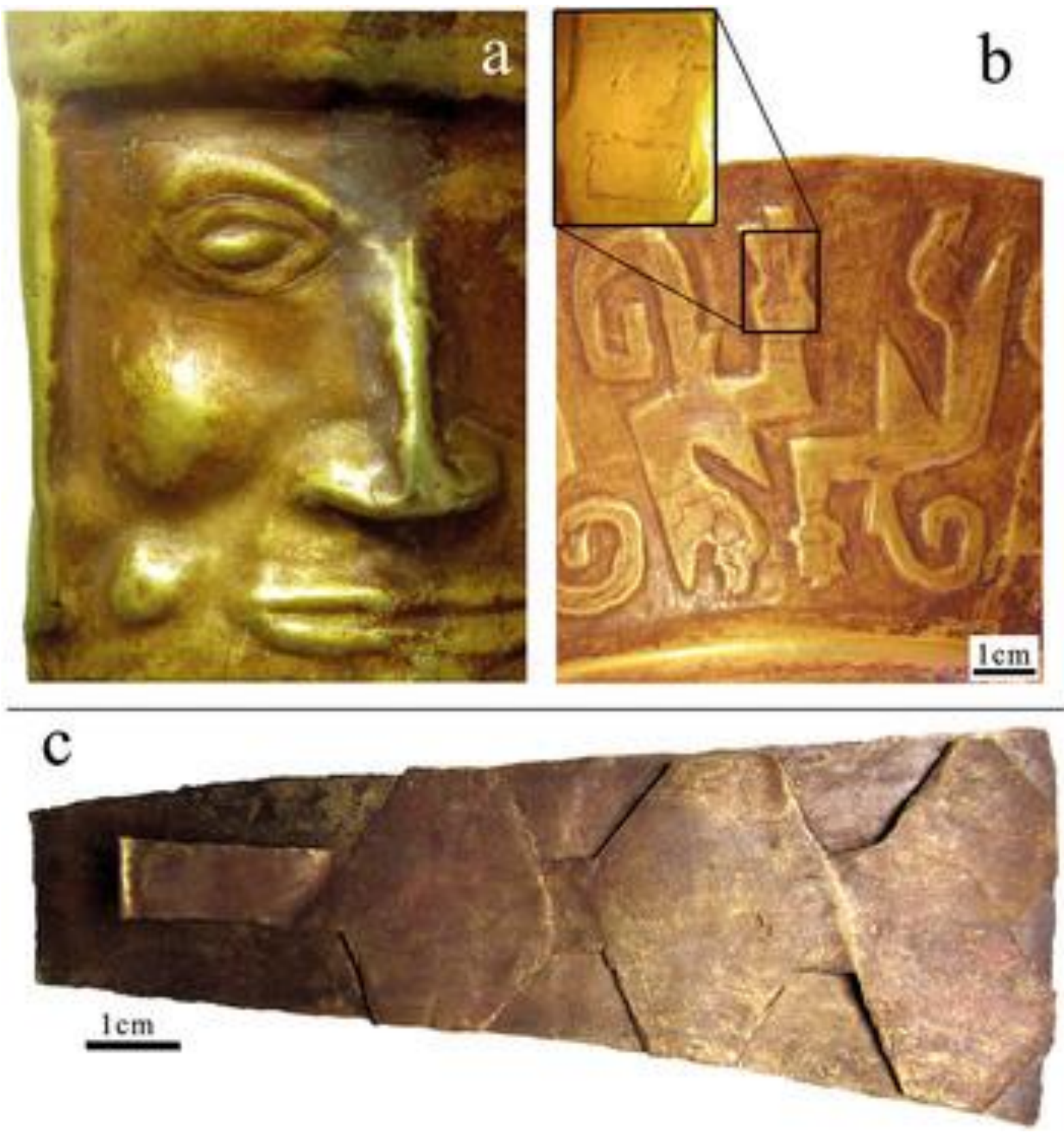

Figure 6. Details of manufacture and decoration techniques: (a) chiselling in portrait vessel 18.087; (b) chasing, embossing and pointillism in kero 18.088; (c) headdresses 18.111 and 18.112. (Photographs: M.T. Plaza.)

In the three goblets, vertical or horizontal joint marks were not found anywhere. This absence of joint lines suggests the use of raising as the main forming technique, as described by Carcedo and colleagues (2004, fig. 10). Surfaces were polished in all cases, but there are different manufacturing traits in each case. For example, portrait-vessel 18.087 has a flat base, whereas kero 18.089 has a circle drawn on the base, imitating a concave base; and kero 18.088 has a low concave base. Rims are different as well: in 18.087 the rim is inturned, whereas in 18.089 and 18.088 the rim is everted. Further, the rim of 18.089 has a pronounced external thickening that is absent in 18.088. Dimensions are variable as well, with estimated volumes of $0.3 \mathrm{l}$ (18.087), $2.5 \mathrm{l}$ (18.088) and $3.0 \mathrm{l}$ (18.089). Keros 18.088 and 18.089 were carefully flattened, showing no visible blows, pointing to a ritual killing of the goblets. Despite the fact that the same techniques were used to decorate the three cups, i.e. embossing, chasing and chiselling, these were combined differently. In the case of the portrait vessel 18.087 , the face was made by chasing, probably using a wooden mould from the inside 
(Carcedo et al. 2004, figs 10-11). Chiselling was applied afterwards to retouch the features of the face (Fig. 6 a). In 18.088, embossing, chasing, chiselling and pointillism were used to create low-relief creatures, double torus and horizontal S volutes (Figs $6 \mathrm{~b}, \underline{8 \mathrm{e}}$ ). The rounded torus of vessel 18.089 was made by embossing from the interior and chiselling from the front. The differences between these goblets suggest that they were made independently; the three of them, however, display skill and knowledge in a range of techniques that are conspicuously absent in the rest of the assemblage (Kuijpers 2015; 2017; 2018).

Finally, there are six very thin sheet fragments; some of them are cut and others are just broken fragments (CP16, 1086, 18.113-18.116). Their manufacture traits show no particular characteristics, thus they were not included in any of the groups (Fig. 2 B7, B16).

b. Technology and reuse

In broad terms, we can identify two groups of objects based on the quality of the manufacturing techniques (Table 2 b). The largest group comprises 20 objects (57 per cent) showing rather crude, arguably 'poor' craftsmanship (Craft Group 1); the second group is made of seven objects (20 per cent) showing more careful manufacture and 'better' finished work (Craft Group 2). The six sheet fragments (17 per cent) of undetermined manufacture traits are not considered in these groups. We propose that both groups include imported objects, probably from different areas and certainly made by a range of artisans with diverse skills and different levels of expertise (Kuijpers $\underline{2015} ; \underline{2017} ; \underline{2018}$ ). There is not enough evidence to suggest the possible origins of the objects in Group 1; as for Group 2, the quality, design and decoration of some of these objects clearly point to Tiwanaku style. Furthermore, we propose the existence of a local tradition that involved the reshaping and modification of gold (and possibly silver) sheets and finished ornaments, which were cut, hammered and perforated when adapted to local taste or need. In this sense, it is possible that some of the objects in the first group may originally have been part of larger artefacts of better craftmanship (i.e. Group 2), which had the evidence for skilled and careful work obliterated by the subsequent reshaping. Group 1 includes three headdresses $(18.096,18.102,18.107)$, two headbands $(18.091,18.092)$, a ring (18.119) and series of sheets and pendants (18.093-18.095, 18.097-18.101, 18.103$18.106,18.109-18.110)$. In general, none or only one surface is polished; edges are uneven, unpolished and worn; perforations are circular, made with a pointy tool (e.g. a needle) and leaving untreated burrs. Compositions are variable, but always with silver levels equal to or higher than 30 per cent (Fig. 7). 


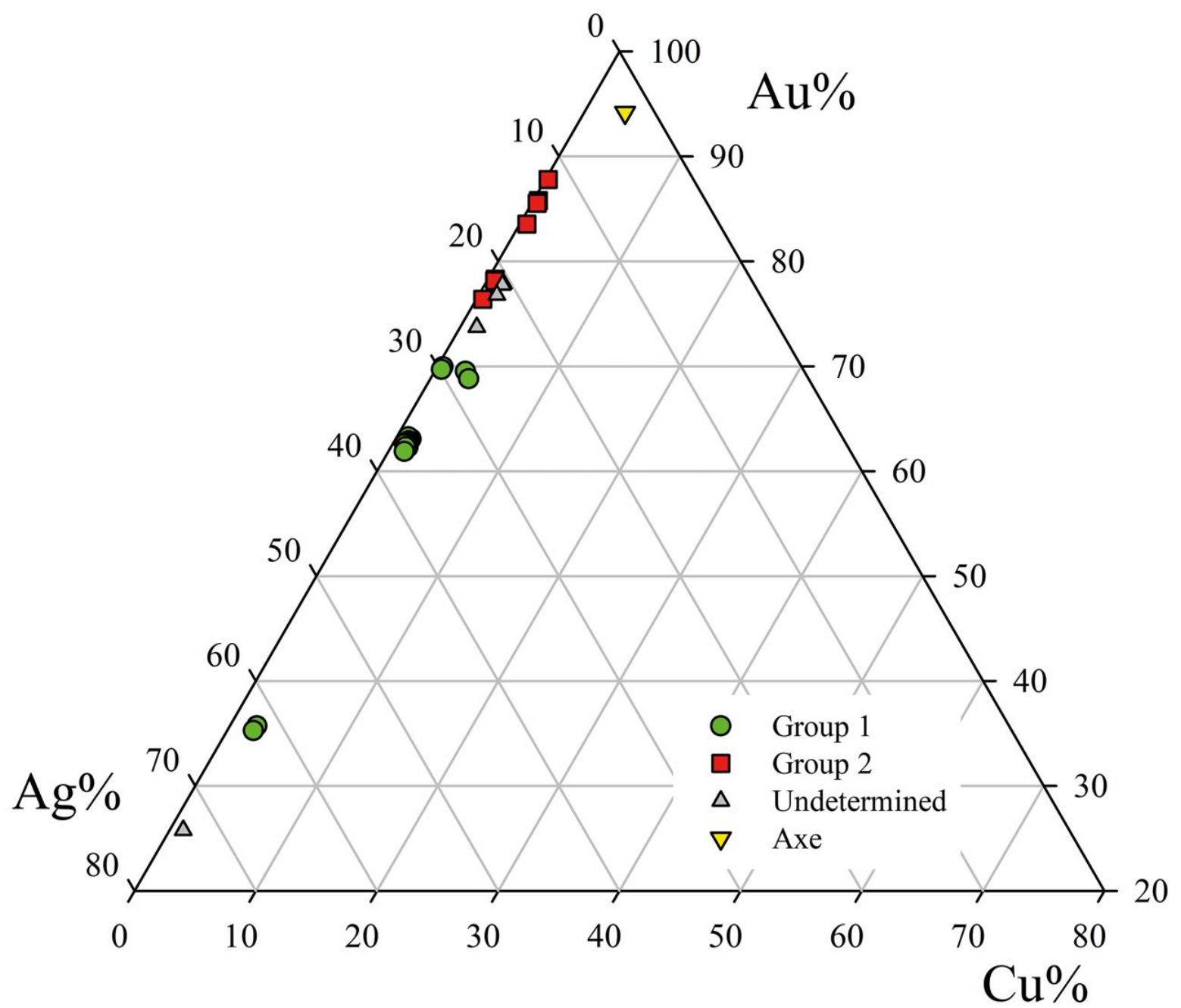

Figure 7. Gold-silver-copper ternary diagram presenting the bulk chemical composition of the 33 gold grave goods from Casa Parroquial, by pXRF. The axe was analysed by ICP-AES (Salazar et al. 2011). Artefacts are organized by technological groups.

Within Group 1 there are three subgroups, each internally consistent in composition and manufacture and thus suggesting that they were made together by the same artisan (Table $2 \mathrm{c}$ ). For example, headbands 18.091 and 18.092 are the only artefacts shaped by folding and cutting a larger gold sheet (Subgroup 1.1), whereas the two-part pendant 18.109 and 18.110 was repaired, perforating both sheets to keep them together (Subgroup 1.2). Subgroup 1.3 comprises 12 sheets that look alike (18.093-18.095, 18.097-18.101, 18.103-18.106). They all bear rough cuts, unpolished edges (with only a few being worn), visible guide lines and untreated needle perforations. This third subgroup shares the same chemical composition as headdresses 18.096, 18.102 and 18.107, but their manufacture traits are slightly different. Headdress 18.107 has worn edges instead of fresh cuts, whereas 18.096 and 18.102 show polished edges and complex designs, compared to the other sheets. Considering the presence of a few worn edges (old edges?), and many fresh cuts in the sheets of Subgroup 1.3, together with the evidence for different manufacture features and old edges in the three headdresses, it is possible to suggest the previous existence of (an) additional ornament(s) made of the same metal, probably as part of a set, which was cut into 12 smaller pieces. Interestingly, the modification marks of these 12 pendants are identical-like headbands 18.091-18.092 and repairs in 18.109-18.110-indicating that were made at the same time by a single artisan following the same working techniques and gestures. Technical gestures and compositional groups that reveal the work of specific artisans have been also identified in Muisca metallurgy from Colombia (Martinón-Torres \& Uribe 2015). 
In contrast with the expediently made pieces of Group 1, in Group 2 we found objects showing a more careful manufacture and better finished work, probably produced by more experienced artisans (Kuijpers 2018). Due to space constraints, we have described only some of them: three goblets (18.087-18.089) and three headdresses $(18.108,18.111,18.112)$, but the group also includes ring 18.090. In general, all these artefacts have their surfaces finely polished, as well as the edges; perforations are retouched (flattened), some artefacts are decorated and designs can be more complex. Regarding compositions, these seven artefacts have low silver (12-23 per cent) and copper ( $\sim 0.5$ per cent) levels. Interestingly, two of these objects were clearly reshaped using the same untidy techniques found in Group $1 \underline{2}$ (headdresses 18.108 and 18.112). Considering design and decoration, some of the objects in Group 2 can be tracked to other traditions, such as Tiwanaku. For example, the portrait vessel 18.087 represents a man with a hat chewing coca, a common design during the Tiwanaku IV phase, A D 500-800 (Bennett 1934; Flores et al. 1998; Janusek 2003). Ceramic goblets with the same figure are found in Pariti Island (Fig. 8 a) (Sagárnaga 2007, fig. 1), while a stone specimen is held at the Ethnologisches Museum zu Berlin (ref. V A 64570). Also common in Tiwanaku iconography is the combination of bird, feline and human attributes to create specific motifs (Flores et al. 1998; Janusek 2003), as is the case of the avian design in kero 18.088. Here, the design combines a bird with a wing and a curly tail (Fig. 8 e). A very similar avian design is described by Posnansky (1957, pl. LI) in a kero from Cochabamba (Fig. 8 d); as well as in pottery and lapidary work from Tiwanaku (Bennett 1934, figs 15, 17, 21; Posnansky 1957, pls 28a, 35c, 37a-b). In SPA both connections are possible, given the evidence of pottery, textiles and snuffing implements with styles from the Titicaca basin, as well as textiles and pottery with Tiwanaku variants from Cochabamba valley (Oakland 1992; Stovel 2008; Uribe \& Agüero 2001). Finally, headdresses such as 18.108 are more difficult to trace, but similar ornaments are reported in northwest Argentina (Fig. $8 \mathrm{c}$ ) and Copiapo, Chile (Fig. 8 b). Specialists, however, believe these ornaments are more likely to originate in northwest Argentina (H. Horta, pers. comm. 2016).
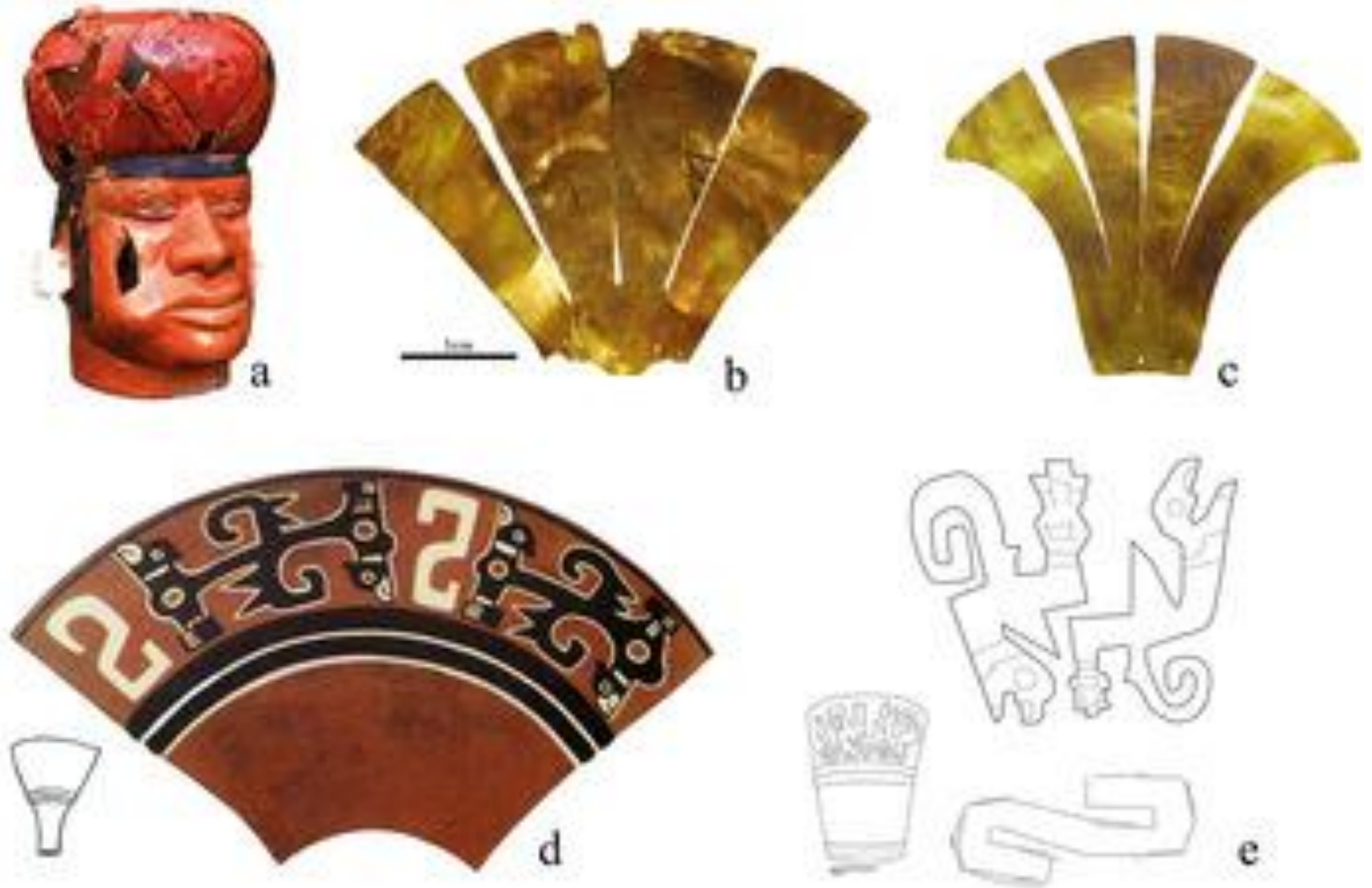

Figure 8. (a) Portrait-vessel from Pariti Island (modified from Sagárnaga 2007, fig. 1); (b) headdress no. 2611 found in Copiapo, Chile, Collection of the Museo Chileno de Arte Precolombino (photograph: M.T. Plaza); (c) headdress from northwest Argentina (modified from González 2006, 252); (d) avian motif in a kero from Cochabamba (after Posnansky 1957, pl. LI); (e) detail of kero 18.088 (drawing: M.T. Plaza). 
The three subgroups in Group 1, as well as the headdresses 18.108 and 18.112 in Group 2, are basically objects that were modified or reshaped using relatively simple mechanical means: punching, cutting and folding (Table $2 \mathrm{~d}$ ). Noteworthy is the shortage of solutions involving melting metal, which suggests a lack of knowledge of (or interest in) those metallurgical processes. Assuming that this reshaping took place locally in SPA, the absence of local hightemperature technology would also mean that SPA artisans did not necessarily melt gold to produce their ornaments, but they obtained finished artefacts that they modified according their taste or needs. In this case, cutting and punching were the main working techniques, requiring tools such as chisels, needles and burins, already available in San Pedro and extensively used in other industries such as bone and wooden sculpture (Horta 2014; Salazar et al. 2014). The modification of gold objects would support the multi-crafting background of San Pedro society, where non-specialists worked different materials and participated in a range of different activities and tasks, in either an opportunistic or a communally regulated way (Castro et al. 2016; Crumley 1995; 2007; DeMarrais 2013; Nielsen 2006; 2007). Having said this, we should note that the chemical overlap between craft groups 1 and 2 is limited, contrary to what we would expect if finer objects were routinely being cut and reshaped. Furthermore, objects in Group 1 are typically the ones richer in silver, which would necessarily require hightemperature alloying or recycling (Fig. 7). In particular, above 30 per cent Ag there are three compositional modes with $\sim 36$ per cent Ag, 62 per cent Ag and 73 per cent Ag, representing at least three melting episodes. Unfortunately, we do not have enough evidence to propose that the melting process took place in San Pedro; analyses of the few crucibles and moulds found in SPA would be necessary to explore this possibility (Cifuentes et al. 2018). Alternatively, it is perhaps more likely that both the gold-rich and the silver-rich alloys arrived at SPA readily alloyed and, once there, the basic work of reshaping them-as seen in CP-became a local activity, produced by non-metallurgist multi-craft artisans. If this was consistently the case, however, we would expect more compositional overlap between both groups.

\section{Final considerations}

Distribution and meaning of the offerings: the local perspective

Some patterns are observed in the distribution of the gold offerings in CP. In terms of quantity and types of objects, there are two burials with over six items (18 and 16), whereas the other burials have only one or two ornaments. It is interesting that in burials with two items, these have the same composition, forming a set. This suggests that, in general, most people in CP would have had access to only one gold object; when they had two, those were acquired at the same time. A different example is burial 7, where a child was buried with five thin sheets of different compositions. The group appears to be made of fragments of larger sheets that were collected and deposited with the child. The quality of these offerings is low compared to those of other burials.

Individual 18 is an adult male with six gold items, among them an axe, two keros and a wooden tube wrapped in a gold sheet. All of them are significant elements used as power emblems and ritual elements in SPA (Horta 2014; Llagostera et al. 1988; Salazar et al. 2014), suggesting that the individual played an important role within his community, maybe a chief or a shaman. In terms of composition and manufacture, this burial is very diverse, comprising a broad range of alloys (Fig. 3 ) and different qualities of manufacture, including the keros with Tiwanaku designs. This diversity suggests that the offerings grouped here were acquired from different sources and, most likely, during the lifetime of the individual.

The funerary assemblage for this individual includes square sheet 18.093 from craft subgroup 1.3. The remaining 11 sheets in this subgroup were found in burial 16, together with two headdresses of the same composition as grave goods of two newborns buried together. The gold offerings in burial 16 form two identical sets: a large band, a rectangular sheet with four small pendants at each corner, and a headdress for each baby. In contrast to burial 18, here the 
compositions and manufacture of the items are the same (Table $2 \mathrm{a}, \mathrm{b})$. Considering that the individuals are newborns (and thus unable to acquire these objects by themselves), and the similarities in composition and manufacture within the group of offerings, we believe that the quadrangular sheets were cut at the same time out of a single sheet of gold, especially for the burial of these babies, intentionally producing identical sets.

The connection between burials 18 and 16 is less clear, even if both have sheets of the same group, together with the headdress of burial 11, also of identical composition. They may represent family relationships, inherited objects, or merely exchange between people of the same community. Nonetheless, it is likely that these deaths were not very distant in time, and individuals were possibly related. It does not look like a coincidence that burials 18 and 16 contain more gold offerings than the others; and the fact that one of them was two newborns suggests that the family of those children would have had access to more than one gold artefact-as is the case for the individual in burial 18.

Building upon the variety of types, compositions and qualities of gold grave goods found in CP, especially the presence of incomplete or fragmented ornaments, we propose that gold in the SPA society had multiple meanings that operated at different levels and that were intentionally expressed in the funerary ritual (Berenguer 1994). On the one hand, there are artefacts considered emblems of political (axes) and religious leadership (keros, portrait-cup), relating CP to Tiwanaku. Gold in this case was most likely used to show rank, leadership and affiliation with Tiwanaku, showing the importance and great symbolism of this metal to communicate political and religious messages (DeMarrais et al. 1996; González 2004b; Lechtman 1993).

On the other hand, there are relatively small and plain sheets (e.g. burial 7), relatively poorly made or modified items that were also part of the funerary ritual. In this case, objects may reveal something different, where the presence of the metal or a piece of an object in the offering was more important than the objects itself, its quality or the skill invested to make it. As Nielsen (2007) argues, the role of foreign and exotic items in the SCA was varied and it goes beyond their use as 'elite' objects. These items actively participated in the construction of gender or social identities and, in many cases, the value of these artefacts resides in their ability to signify multi-ethnic and multi-ecological integration (Nielsen 2007, 407). These items, regarding their quality, can also carry stories and memories of people and places that participate in people's daily life (Lazzari 2016, 4), as well as transferring sacredness from their place of origin (Ogburn 2004). This may be the case for the more 'humble' gold objects found in $\mathrm{CP}$, where value does not seem to be in the object style or technical mastery, but most likely in the symbolism of the material itself, the life-histories behind each item including its origins, its transport, its use (or not) and its physical change in local hands-all potentially adding layers of meaning and value (Gosden \& Marshall 1999; Helms 1993; Horta 2012; Joyce \& Gillespie 2015; Kopytoff 1986; Lazzari 2016; Spielmann 1998). Similar notions have been used to interpret the presence of foreign pottery in SPA (Stovel 2008) and the circulation of lithics (Lazzari 2016; Ogburn 2004) or spondylus (Glowacki \& Malpass 2003; Paulsen 1974) in the Andes.

\section{Gold circulation and technology in the SCA: the regional perspective}

Chemical and technical analysis of the gold grave goods from CP provides useful insight regarding gold circulation and production in the SCA, during the MP. Firstly, we identify a range of compositions and manufacture styles and skills, indicating that these objects-usually defined as part of a 'sheet technology' (González 2004a) - reveal more complexity than expected. Overall, the evidence indicates that gold artefacts found in CP were imported. Secondly, it has been assumed that the gold found in SPA arrived from Tiwanaku, and it was used to represent the connection with the Altiplanic polity (Salazar et al. 2014). Our research challenges this view, indicating that these connections can be expanded to Cochabamba and NWA as well. This panorama exposes the complexity of the gold circulation network, expanding its limits to all the SCA including the Circumpuna. It also questions the reason why gold was used in SPA (see previous section). Gold not only relates elites to Tiwanaku, but it also suggests 
more frequent relationships with neighbouring areas, such as NWA, by exchanging small, simple or incomplete items. Still, this is a first step and future research including a larger sample and considering trace elements will provide better evidence to support these results, linking SPA to other regions.

Thirdly, the variability identified suggests that several people were working this metal, showing different degrees of expertise, probably related to different ways of organizing production.

Increasing the sample would help to clarify whether workshops, independent artisans, or both, were involved in their production. However, the presence of complex and high-quality techniques, such as those seen in the keros and portrait-cup, would suggest a controlled production, probably with artisans working in workshops, training and sharing a technological style, as has been reported in Tiwanaku for the production of pottery and musical instruments (Janusek 1999). Conversely, the local modifications and the presence of small plain pendants and bands of varied qualities point towards an independent production, characteristic of the communities from the Circumpuna-including SPA-described as corporative and heterarchical, with a decentralized economic and political organization (Castro et al. 2016; Nielsen 2006). In SPA, the presence of toolkits to produce different crafts (e.g. beads, weaving, woodwork, smelting) found in association with the same individuals in cemeteries from Solcor, Coyo and Quitor, would support the idea of multi-crafting activities (Horta \& Faundes 2018; Salazar et al. 2014). We propose here that the local modifications of gold grave goods are actually part of the multi-crafting activities practised by SPA's artisans; therefore, the re-use of gold items in CP did not require the presence of specialized metallurgists.

\section{Conclusions}

The scientific study of gold offerings from Casa Parroquial has provided useful insight into the use of gold and the technology present in San Pedro de Atacama, along with the capability to identify specific artisans, as well as craftspeople with different skill levels. The detailed observation of manufacture traits combined with their elemental composition has revealed the complex life-histories of these offerings, which changed through time.

Chemical composition and manufacture techniques indicate that objects were predominantly made by hammering both unalloyed gold and artificial gold-silver alloys of variable composition. We identified two main working styles or 'craft groups', one more careful than the other, probably representing various artisans with different skill levels. At the same time, there were obvious overlaps between the two working styles, indicating that carefully crafted objects were cut, reshaped and adjusted more crudely at a later stage of their life. There is no evidence to suggest that gold objects were made in SPA; most likely, they are imported objects arriving from Tiwanaku or Cochabamba and northwest Argentina, revealing intricate biographies and circulation patterns. Nevertheless, it is likely that many of these ornaments were modified or reshaped in SPA, either as they entered this new cultural context or as part of the funerary ritual. The latter is most probably the case for two keros that seem ritually killed, and the pendants with fresh cuts and perforations and with no evidence of use after their modification. Rather than specialized metallurgical skills, it would seem that artisans in SPA were engaged in multi-crafting and modified gold and silver objects using their experience of other local crafts, such as wooden or bone sculpture, without resorting to high-temperature melting or casting. The distribution of gold shows that seven out of ten people buried with gold have one or two items; exceptions are the male in burial 18 and the newborns in burials 16 and 7. The type of offerings in burial 18 suggests that he was an important person in his community: the keros and the inhalation tube are associated with ritual activities and ceremonies, whilst the axe is considered a symbol of power. We believe this person may be related to the newborns in burial 16, mainly because they share objects of identical composition and manufacture traits, and due to the unusual amount of gold offerings associated with those children. The presence of gold in child burials would support the idea of increasing social complexity, manifested in inheritable wealth and status during the MP. At the same time, the predominance of very small sheet 
fragments of sheet gold, silver and their alloys, often crudely cut and pierced, indicates that these metals primarily had an intrinsic value that was not related to aesthetic appeal or craftmanship. It is not possible at this stage to determine the geological source(s) of these metals, or indeed whether their potentially exotic origins (culturally or geographically) may have added to the social value of these items. In any case, it is obvious that most of these objects had complex life-histories that affected their materiality from the original manufacture to their final deposition. As such, understanding their cultural value requires much more than tracing them to a geological source.

\section{Supplemental Materials}

The supplementary materials for this article can be found at https://doi.org/10.1017/S0959774321000123

\section{Acknowledgements}

We are very grateful to Valentina Figueroa-Larre from the Instituto de Arqueología y Antropología of the Universidad Católica del Norte, and to the staff at the Museo Arqueológico R.P. Gustavo Le Paige s.j., San Pedro de Atacama, especially Jimena Cruz, Arturo Torres and Saúl Cervantes for facilitating access to the artefacts and museum records; to the staff of the UCL Wolfson Archaeological Science Laboratories for their guidance and training; to Benoit Mille and Quentin Lemasson at the AGLAE laboratory of the Centre de Recherche et de Restauration des Musées de France (C2RMF) for training and processing PIXE data. This project was funded thanks to the Chilean Government and CONICYT (Becas Chile Postdoctorado); ANID projects 3200229, 11130651 and 1160849; UCL Institute of Archaeology; and The Coghlan Bequest funding of the Historical Metallurgy Society. Financial support by the Access to Research Infrastructures activity in the 7th Framework Programme of the EU (CHARISMA Grant Agreement n. 228330) is gratefully acknowledged.

\section{Footnotes}

1. We describe the marks as 'rough and careless' only from an analytical perspective, when comparing the quality of the manufacture marks in detail. However, we are aware that the quality difference identified under the microscope was not necessarily perceived as such for the users in the past.

2. In this sense, we should acknowledge that if an object was substantially modified, erasing evidence from original high-quality manufacture, we would probably have classified it as a Group 1.

\section{References}

Alarcón, H. \& Fornari, M., 1994. Análisis de oro por microsonda (E.P.M.A.) en depósitos primarios de oro de la provincia metalogénica andina de Bolivia y su significado genético [Analysis of gold by microprobe (E.P.M.A.) in primary gold deposits of the Andean metallogenic province of Bolivia and its genetic significance], in Memorias Del XI Congreso Geológico de Bolivia [Proceedings of the XI Bolivian Geology Conference], eds Boliviana, Sociedad Geológica. Santa Cruz: Sociedad Geológica Boliviana, 304-11.Google Scholar@cam - find full text

Aldenderfer, M., Craig, N.M., Speakman, R.J. \& Popelka-Filcoff, R., 2008. Four-thousand-year-old gold artifacts from the Lake Titicaca basin, southern Peru. Proceedings of the National Academy of Sciences 105(13), 5002-5.CrossRefGoogle ScholarPubMed@cam - find full text 
Angiorama, C.I., 2001. De metales, minerales y yacimientos. Contribución al estudio de la metalurgia prehispánica en el extremo noroccidental de Argentina [Of metals, minerals and deposits. Contribution to the study of pre-Hispanic metallurgy in the north-west extreme of Argentina]. Estudios Atacameños 21, 63-87.CrossRefGoogle Scholar@cam - find full text

Angiorama, C.I., 2004. Estudio de objetos de oro prehispánicos procedentes de Los Amarillos (Jujuy, Argentina) [Study of prehispanic gold objects from Los Amarillos (Jujuy, Argentina)], in Tecnología Del Oro Antiguo: Europa y América. Anejos de Archivo Español de Arqueología XXXII [Ancient gold technology: Europe and America. Annexes to the Spanish Archaeology Archive XXXII], eds Perea, A., Montero, I. \& García-Vuelta, Ó.. Madrid: Consejo Superior de Investigaciones Científicas, 149-56.Google Scholar@cam - find full text

Barón, A.M., 2004. Excavación del cementerio de Larache, Conde Duque en San Pedro de Atacama [Excavation of the Larache, Conde Duque cemetery in San Pedro de Atacama], in Tiwanaku. Aproximaciones a Sus Contextos Históricos y Sociales [Tiwanaku. Approaches to its historical and social contexts], eds Rivera, M. \& Kolata, A.. Santiago: Universidad Bolivariana, 67-97.Google Scholar@cam - find full text

Benavente, A., Massone, C. \& Thomas, C., 1986. Larrache, evidencias atípicas. ¿Tiahuanaco en San Pedro de Atacama? [Larrache, atypical evidence. Tiahuanaco in San Pedro de Atacama?]. Chungará (Arica) 16-17, 67-73.Google Scholar@cam - find full text

Bennett, W., 1934. Excavations at Tiahuanaco. Anthropological Papers of The American Museum of Natural History 34(3), 350-494.Google Scholar@cam - find full text

Bennett, W., 1936. Excavations in Bolivia. Anthropological papers of The American Museum of Natural History 35(5), 194.Google Scholar@cam - find full text

Berenguer, J., 1994. La muerte como un discurso para los vivos: Hacia una semiótica de la evidencia funeraria [Death as a discourse for the living: towards a semiotics of funerary evidence]. Boletín de la Sociedad Chilena de Arqueología 19, 23-7.Google Scholar @cam - find full text

Berenguer, J., 1998. La iconografía del poder en Tiwanaku y su rol en la integración de zonas de frontera [The iconography of power in Tiwanaku and its role in the integration of border areas]. Boletín del Museo Chileno de Arte Precolombino 7, 19-37.Google Scholar @am - find full text

Berenguer, J., Castro, V. \& Silva, O., 1980. Reflexiones acerca de la presencia de Tiwanaku en el norte de Chile [Thoughts about the presence of Tiwanaku in northern Chile]. Estudios Arqueológicos 5, 81-93.Google Scholar@cam - find full text

Boric, R., Díaz, F. \& Maksaev, V., 1990. Geología y Yacimientos Metalíferos de La Región de Antofagasta [Geology and metalliferous deposits of the Antofagasta Region]. (Boletín 40.) Santiago: Servicio Nacional de Geología y Minería de Chile.Google Scholar @cam - find full text

Carcedo, P., Vetter, L. \& Canseco, M.D., 2004. Los vasos-efigie antropomorfos: un ejemplo de la orfebrería de la costa central durante el Periodo Intermedio Tardío y el Horizonte Tardío 
[Anthropomorphic effigy vases: a silvermith's production during the Late Intermediate period and Late Horizon]. Boletín de Arqueología PUCP 8, 151-89.Google Scholar@cam - find full text

Castro, V., Berenguer, J., Gallardo, F., Llagostera, A. \& Salazar, D., 2016. Vertiente Occidental Circumpuneña. Desde las sociedades postarcaicas hasta las preincas (ca. 1.500 años a.C. a 1.470 años d.C) [The western Circumpuna. From the postarchaic societies to the pre-Inca ( $c a .1500 \mathrm{BC}$ to AD 1470)], in Prehistoria En Chile. Desde Sus Primeros Habitantes Hasta Los Incas [Prehistory in Chile. From its first inhabitants to the Incas], eds Falabella G, F.., Uribe, M., Sanhueza, L., Aldunate, C. \& Hidalgo, J.. Santiago: Editorial Universitaria, 23784.Google Scholar@cam - find full text

Chapman, R.J., Leake, B. \& Styles, M., 2002. Microchemical characterization of alluvial gold grains as an exploration tool. Gold Bulletin 35(2), 53-65.CrossRefGoogle Scholar@cam - find full text

Cifuentes, A., Figueroa-Larre, V., Salazar, D. \& Mille, B., 2018. Producción metalúrgica local y coexistencia de tecnologías metalúrgicas en San Pedro de Atacama durante el Período Medio (400-1000 DC) [Local metal production and coexistence of metallurgical technologies in San Pedro de Atacama during the Middle Period (AD 400-1000)]. Chungará 50(3), 423-39.Google Scholar@cam - find full text

Crumley, C., 1995. Heterarchy and the analysis of complex societies., in Heterarchy and the Analysis of Complex Societies, eds Ehrenreich, R.M., Crumley, C. \& Levy, J.E.. (Archeological Papers 6.) Arlington (VA): American Anthropological Association, 1-6.Google Scholar @am - find full text

Crumley, C., 2007. Notes on a new paradigm, in Socialising Complexity: Approaches to power and interaction in the archaeological record, eds. Kohring, S. \& Wynne-Jones, S.. Oxford: Oxbow, 3036.Google Scholar@cam - find full text

DeMarrais, E., 2013. Art as an affecting presence: infant funerary urns in pre-Hispanic northwest Argentina. World Art 3(1), 101-19.CrossRefGoogle Scholar@cam - find full text

DeMarrais, E., Castillo, L.J. \& Earle, T., 1996. Ideology, materialization, and power strategies. Current Anthropology 37(1), 15-31.CrossRefGoogle Scholar@cam - find full text

Dillehay, T. \& Núñez, L., 1988. Camelids, caravans and complex societies in the South-Central Andes, in Recent Studies in Pre-Columbian Archaeology vol 2, eds Saunders, N. \& Montmollin, O.. (BAR International series S421.) Oxford: British Archaeological Reports, 603-34.Google Scholar @cam - find full text

Flores, J., Kuon, E. \& Samanez, R., 1998. Qeros. Arte Inka En Vasos Ceremoniales [Qeros. Inka art in ceremonial cups]. Lima: Banco de Crédito del Perú.Google Scholar@cam - find full text

Glowacki, M. \& Malpass, M., 2003. Water, huacas, and ancestor worship: traces of a sacred Wari landscape. Latin American Antiquity 14(4), 431-48.CrossRefGoogle Scholar@cam - find full text

González, L.R., 2003. El oro en el noroeste argentino prehispanico. estudios tecnicos sobre dos objetos de la Casa Morada de la Paya [Gold in pre-Hispanic northwest Argentina. Technical studies on two objects from the Casa Morada de la Paya]. Relaciones de la Sociedad Argentina de Antropología 28, 75-99.Google Scholar@cam - find full text 
González, L.R., 2004a. El oro y el moro. Tecnología y universo simbólico en el Noroeste Argentino Prehispánico ['El oro y el moro'. Technology and symbolic universe in prehispanic northwest Argentina], in Tecnología Del Oro Antiguo: Europa y América. Anejos de Archivo Español de Arqueología XXXII [Ancient gold technology: Europe and America. Annexes to the Spanish Archaeology Archive XXXII], eds Perea, A., Montero, I. \& García-

Vuelta, Ó.. Madrid: Consejo Superior de Investigaciones Científicas, 329-37.Google Scholar @cam - find full text

González, L.R., 2004b. Bronces Sin Nombre. La Metalurgia Prehispánica En El Norte Argentino [Bronzes with no names. Pre-Hispanic metallurgy in northern Argentina]. Buenos Aires: Fundación Ceppa.Google Scholar@cam - find full text

González, L.R., 2006. El poder de los metales [The power of metals], in Tesoros Precolombinos Del Noroeste Argentino [Precolumbian treasures from northwest Argentina],

ed. Goretti, M.. Buenos Aires: Fundación Ceppa, 93-263.Google Scholar@cam - find full text

González, L.R. \& Vargas, A., 1999. Tecnología metalúrgica y organización social en el noroeste argentino prehispánico [Metallurgical technology and social organisation in prehispanic northwest Argentina]. Chungará (Arica) 31(1), 5-27.Google Scholar@cam - find full text

Gosden, C. \& Marshall, Y., 1999. The cultural biography of objects. World

Archaeology 31(2), 169-78.CrossRefGoogle Scholar@cam - find full text

Guerra, M.F. \& Calligaro, T., 2004. Gold traces to trace gold. Journal of Archaeological Science 31(9), 1199-208.CrossRefGoogle Scholar@cam - find full text

Guerra, M.F., Fernández, S., Delaveris, I., Encuentra, J.O. \& Villanueva, J., 2019. Small gold bells and miniature keros: an approach to understanding the technologies and alloys employed in Pre-Columbian Andes. Journal of Archaeological Science: Reports 24, 967-77.CrossRefGoogle Scholar@cam - find full text

Guerra, M.F. \& Rehren, T., 2009. In-situ examination and analysis of the gold jewellery from the Phoenician tomb of Kition (Cyprus). ArcheoSciences (33), 151-8.CrossRefGoogle Scholar @cam - find full text

Hauptmann, A. \& Klein, S., 2009. Bronze Age gold in southern Georgia. ArchéoSciences (33), 7582.CrossRefGoogle Scholar@am - find full text

Helms, M., 1993. Crafts and the Kingly Ideal. Art, trade and power. Austin (TX): University of Texas Press.Google Scholar@cam - find full text

Hérail, G., Fornari, M., Viscarra, G. \& Miranda, V., 1990. Morphological and chemical evolution of gold grains during the formation of a polygenic fluviatile placer: the Mio-pleistocene Tipuani placer example (Andes, Bolivia). Chronique de la Recherche Minière 500, 41-9. Google Scholar @cam - find full text

Hérail, G., Lagos, J. \& Vivallo, W., 1999. Gold dispersion in Andean desert environments (Atacama, Chile). Journal of Geochemical Exploration 66(3), 427-39.CrossRefGoogle Scholar @cam - find full text 
Horta, H., 2012. El Estilo Circumpuneño en el arte de la parafernalia alucinógena prehispánica (Atacama y Noroeste Argentino) [The Circumpuneño Style in the art of prehispanic hallucinogenic paraphernalia (Atacama and Northwest Argentina)]. Estudios

Atacameños (43), 5-34.CrossRefGoogle Scholar@cam - find full text

Horta, H., 2014. Lo propio y lo ajeno: definición del estilo San Pedro en la parafernalia alucinógena de los oasis del Salar de Atacama [Local and introduced styles in the hallucinogenic paraphernalia of the Salar de Atacama oases]. Chungará (Arica) 46(4), 559-83.CrossRefGoogle Scholar@cam-find full text

Horta, H. \& Faundes, W., 2018. Manufactura de cuentas de mineral de cobre en Atacama (Chile) durante el Período Medio (ca. 400-1.000 dC): Nuevas evidencias contextuales y aportes desde la experimentación arqueológica [Manufacture of copper ore beads in Atacama (Chile) during the Middle Horizon (ca. AD 400-1000): New contextual evidences and contributions from experimental archeology]. Chungará (Arica) 50(3), 397-422.Google Scholar@cam - find full text

Hough, R., Butt, C. \& Fischer-Bühner, J., 2009. The crystallography, metallography and composition of gold. Elements 5(5), 297-302.CrossRefGoogle Scholar@cam - find full text

Janusek, J.W., 1999. Craft and local power: embedded specialization in Tiwanaku cities. Latin American Antiquity 10(2), 107-31.CrossRefGoogle Scholar@cam - find full text

Janusek, J.W., 2003. Vessels, time and society. Toward a ceramic chronology on the Tiwanaku heartland, in Tiwanaku and Its Hinterland. Vol. 2, Urban and Rural Archaeology, ed. Kolata, A.. Washington (DC): Smithsonian Institution Press, 30-91.Google Scholar @cam - find full text

Joyce, R. \& Gillespie, S., 2015. Making things out of objects that move, in Things in Motion. Object itineraries in anthropological practice, eds Joyce, R. \& Gillespie, S.. Santa Fe (NM): School of Advanced Research Press, 3-19.Google Scholar@cam - find full text

Kopytoff, I., 1986. The cultural biography of things: commoditization as process, in The Social Life of Things: Commodities in cultural perspective, ed. Appadurai, A.. Cambridge: Cambridge University Press, 64-91.CrossRefGoogle Scholar@cam - find full text

Korpisaari, A., 2006. Death in the Bolivian High Plateau: Burials and Tiwanaku society. (BAR International series 1536). Oxford: Archaeopress.CrossRefGoogle Scholar@cam - find full text

Korpisaari, A., Sagárnaga, J. \& Väisänen, R., 2011. Archaeological Excavations on the Island of Pariti, Bolivia: New light on the Tiwanaku Period in the Lake Titikaka Region. (Ancient America 11.) Barnardsville (NC): Boundary End Archaeology Research Center.Google Scholar @cam - find full text

Kuijpers, M.H.G., 2015. Some thoughts on quality and skill in Early Bronze Age axes, in Metaaltijden 2. Bijdragen in de Studie van de Metaaltijden [Metal Ages 2. Contributions to the Study of the Metal Ages], eds Ball, E.A.G. \& Arnoldussen, S.. Leiden: Sidestone Press, 1928.Google Scholar@cam - find full text 
Kuijpers, M.H.G., 2017. The Bronze Age, a world of specialists? Metalworking from the perspective of skill and material specialization. European Journal of Archaeology 21(4), 55071.CrossRefGoogle Scholar@cam - find full text

Kuijpers, M.H.G., 2018. A sensory update to the chaine opératoire in order to study skill: perceptive categories for copper-compositions in archaeometallurgy. Journal of Archaeological Method and Theory 25(3), 863-91.CrossRefGoogle ScholarPubMed@cam - find full text

Lazzari, M., 2016. Stones to build a world: circulation and value of materials in pre-Columbian northwestern Argentina. Cambridge Archaeological Journal 26(1), 1-22.CrossRefGoogle Scholar @cam - find full text

Lechtman, H., 1978. Temas de Metalurgia Andina [Andean metallurgy issues], in Tecnología Andina [Andean Technology], ed. Ravines, R.. Lima: Instituto de Estudios Peruanos (IEP)/Instituto de Investigación Tecnológica, Industrial y de Normas Técnicas, 489-520.Google Scholar@cam - find full text

Lechtman, H., 1991. Los Orfebres Olvidados de América [The forgotten metalsmiths of America]. Santiago: Museo Chileno de Arte Precolombino.Google Scholar@cam-find full text

Lechtman, H., 1993. Technologies of power: the Andean case, in Configurations of Power: Holisitic anthropology in theory and practice, eds Henderson, J.S. \& Netherly, P.. New York (NY): Cornell University Press, 244-80.Google Scholar@cam - find full text

Lechtman, H., 1996. El bronce y el horizonte medio [Bronze and the Middle Period]. Boletín Museo del Oro 41, 2-25.Google Scholar@cam - find full text

Lechtman, H., 2014. Andean metallurgy in prehistory, in Archaeometallurgy in Global Perspective: Methods and syntheses, eds Roberts, W.B. \& Thornton, P.C.. New York (NY): Springer, 361-422.CrossRefGoogle Scholar@cam - find full text

Lechtman, H. \& Macfarlane, A., 2005. La metalurgia del bronce en los Andes Sur Centrales: Tiwanaku y San Pedro de Atacama [Bronze metallurgy in the South Central Andes: Tiwanaku and San Pedro de Atacama]. Estudios Atacameños 30, 7-27.Google Scholar@cam - find full text

Lechtman, H. \& Macfarlane, A., 2006. Bronce y redes de intercambio andino durante el Horizonte Medio: Tiwanaku y San Pedro de Atacama [Bronze and Andean exchange networks during the Middle Horizon: Tiwanaku and San Pedro de Atacama], in Esferas de Interacción Prehistóricas y Fronteras Nacionales Modernas: Los Andes Sur Centrales [Prehistoric spheres of interaction and modern national frontiers: The Central South Andes], ed. Lechtman, H.. Lima: Instituto de Estudios Peruanos (IEP)/Institute of Andean Research (IAR), 503-50.Google Scholar@cam - find full text

Llagostera, A., 2004. Los Antiguos Habitantes Del Salar de Atacama: Prehistoria Atacameña [The ancient inhabitants of the Salar de Atacama: Atacama prehistory]. Santiago: Pehuén Editores Limitada.Google Scholar @cam - find full text

Llagostera, A., 2006. San Pedro de Atacama y el sistema reticular de interacción puneña [San Pedro de Atacama and the reticular system of interaction in the Puna], in Esferas de Interacción Prehistóricas y Fronteras Nacionales Modernas: Los Andes Sur Centrales [Prehistoric spheres of 
interaction and modern national frontiers: The Central South Andes], ed. Lechtman, H.. Lima: Instituto de Estudios Peruanos (IEP)/Institute of Andean Research (IAR), 303-28.Google Scholar@cam - find full text

Llagostera, A., Torres, C.M. \& Costa-Junqueira, M.A., 1988. El complejo psicotrópico en Solcor-3 (San Pedro de Atacama) [The psychotropic complex in Solcor-3 (San Pedro de Atacama)]. Estudios Atacameños 9, 67-106.CrossRefGoogle Scholar@cam - find full text

Macfarlane, A.W. \& Lechtman, H.N., 2016. Andean ores, bronze artifacts, and lead isotopes: constraints on metal sources in their geological context. Journal of Archaeological Method and Theory 23, 1-73.CrossRefGoogle Scholar@cam - find full text

Maldonado, B., Rehren, T., Pernicka, E., Núñez, L. \& Leibbrandt, A., 2010. Early copper metallurgy in northern Chile. (Poster), in Metalla. Archäometrie Und Denkmalpflege [Metalla. Archaeometry and monument preservation], eds Hahn, O., Hauptmann, A., ModarressiTehrani, D. \& Prange, M.. Bochum: Museum Bochum, 96-8.Google Scholar@cam - find full text Maldonado, B., Rehren, T., Pernicka, E., Núñez, L. \& Leibbrandt, A., 2013. Early copper metallurgy in northern Chile. Open Journal of Archaeometry 1(1), 26.CrossRefGoogle Scholar @cam - find full text

Martinón-Torres, M. \& Uribe, M.A., 2015. The prehistoric individual, connoisseurship and archaeological science: the Muisca goldwork of Colombia. Journal of Archaeological Science, 63, 136-55.CrossRefGoogle Scholar@cam - find full text

Martinón-Torres, M., Rojas, R.V., Cooper, J. \& Rehren, T., 2007. Metals, microanalysis and meaning: a study of metal objects excavated from the indigenous cemetery of El Chorro de Maíta, Cuba, Journal of Archaeological Science 34(2), 194-204.CrossRefGoogle Scholar @cam - find full text

Martinón-Torres, M., Valcárcel Rojas, R., Sáenz Samper, J. \& Guerra, M.F., 2012. Metallic encounters in Cuba: the technology, exchange and meaning of metals before and after Columbus. Journal of Anthropological Archaeology 31(4), 439-54.CrossRefGoogle Scholar $@$ @am - find full text

McEwan, C. \& Haeberli, J., 2000. Gold diadems from the far south coast of Peru, in Precolumbian Gold. Technology, style and iconography, ed. McEwan, C.. London: Fitzroy Dearborn, 1627.Google Scholar@cam - find full text

Money, M., 1991. El 'tesoro de San Sebastian': una tumba importante de la cultura Tiwanaku [The 'treasure of San Sebastian': an important burial of the Tiwanaku culture]. Beiträge zur allgemeinen und vergleichenden Archäologie 11, 189-98.Google Scholar@cam - find full text

Nielsen, A.E., 2006. Pobres jefes: Aspectos corporativos en las formaciones sociales pre-inkaicas de los andes circumpuneños [Poor bosses: corporate aspects in the pre-Inca social formations of the Circumpunean Andes], in Contra la tiranía tipológica en arqueología. Una visión desde Suramérica [Against typological tyranny in archaeology. A view from South America], eds Gnecco, C. \& Langebaek, C.. Bogotá: Universidad de los Andes, 121-50.Google Scholar $@$ @am - find full text 
Nielsen, A.E., 2007. Bajo el hechizo de los emblemas: políticas corporativas y tráfico interregional en los Andes Circumpuneños [Under the spell of the emblems: corporate policies and interregional traffic in the Circumpunean Andes], in Producción y circulación prehispánicas de bienes en el surandino [Prehispanic production and circulation of goods in the southern Andes], eds Nielsen, A.E., Rivolta, C., Seldes, V., Vázquez, M.M. \& Hercolli, P.. Córdoba: Editorial Brujas, 393-412.Google Scholar@cam - find full text

Oakland, A., 1992. Textiles and ethnicity: Tiwanaku in San Pedro de Atacama, north Chile. Latin American Antiquity 3(4), 316-40.Google Scholar@cam - find full text

Ogburn, D., 2004. Evidence for long-distance transportation of building stones in the Inka Empire, from Cuzco, Peru to Saraguro, Ecuador. Latin American Antiquity 15(4), 41939.CrossRefGoogle Scholar@cam - find full text

Ogden, J., 2000. Metals, in Ancient Egyptian Materials and Technology, eds Nicholson, P. \& Shaw, I.. Cambridge: Cambridge University Press, 148-76.Google Scholar $@$ @am - find full text

Palacios, C., Hérail, G., Townley, B.K., et al. , 2001. The composition of gold in the Cerro Casale gold-rich porphyry deposit, Maricunga belt, Northern Chile. Canadian Mineralogist 39, 90715.CrossRefGoogle Scholar@cam - find full text

Paulsen, A.C., 1974. The thorny oyster and the voice of god: Spondylus and Strombus in Andean prehistory. American Antiquity 39(4), 597-607.CrossRefGoogle Scholar@cam - find full text

Petersen, G., 1970. Minería y metalurgia en el antiguo Perú [Mining and metallurgy in ancient Peru]. Lima.Google Scholar@cam - find full text

Posnansky, A., 1957. Tihuanacu. La cuna del hombre americano [Tihuanacu. The cradle of American man]. Vols III \& IV. La Paz: Ministerio de Educación de Bolivia.Google Scholar @cam - find full text

Ramos, W. \& Fornari, M., 1994. Problemática de la presencia de oro en Los Lípez [The problem of the presence of gold in Los Lípez], in Memorias Del XI Congreso Geológico de Bolivia [Proceedings of the XI Bolivian Geology Conference], ed. Boliviana, Sociedad

Geológica. Santa Cruz: Sociedad Geológica Boliviana, 248-59.Google Scholar@cam - find full text

Root, W.C., 1949. The metallurgy of the southern coast of Peru. American Antiquity 15(1), 10 37.CrossRefGoogle Scholar@cam - find full text

Rovira, S., 1994. Pre-Hispanic goldwork from the Museo de América, Madrid: a new set of analyses, in Archaeometry of Pre-Columbian Sites and Artefacts. (Proceedings of a Symposium Organised by UCLA Institute of Archaeology and the Getty Conservation Institute, March 1992), eds Scott, D.A. \& Meyers, P.. Los Angeles (CA): J.P. Getty Trust, 323-49.Google Scholar @am - find full text

Sáenz Samper, J. \& Martinón-Torres, M., 2017. Depletion gilding, innovation and life-histories: the changing colours of Nahuange metalwork. Antiquity 91, 1253-67.CrossRefGoogle Scholar @am - find full text 
Sagárnaga, J., 2007. Investigaciones arqueológicas en Pariti (Bolivia) [Archaeological investigations in Pariti (Bolivia)]. Anales del Museo de América 15, 67-88.Google Scholar @cam - find full text

Salazar, D., Figueroa-

Larre, V., Morata, D., Mille, B., Manríquez, G. \& Cifuentes, A., 2011. Metalurgia en San Pedro de Atacama Durante el Período Medio?: Nuevos Datos, Nuevas Preguntas [Metal production during the Middle Period in San Pedro de Atacama: New data, new questions]. Revista de

Antropología 23, 123-48.Google Scholar@cam - find full text

Salazar, D., Niemeyer, H.M., Horta, H., Figueroa-Larre, V. \& Manríquez, G., 2014. Interaction, social identity, agency and change during Middle Horizon San Pedro de Atacama (northern Chile): a multidimensional and interdisciplinary perspective. Journal of Anthropological Archaeology 35, 135-52.CrossRefGoogle Scholar@cam - find full text

Samusikov, V.P., 2002. Relationships between Ag and Au in Au-Ag natural system. Russian Geology and Geophysics 43(8), 746-53.Google Scholar@cam - find full text

Schlosser, S., Robert, K., Ernst, P., Detlef, G. \& Tellenbach, M., 2009. Fingerprints in gold, in New Technologies for Archaeology. Multidisciplinary investigations in Palpa and Nasca, Peru, eds Reindel, M. \& Wagner, G.A.. Berlin/Heidelberg: Springer, 409-36.Google Scholar @cam - find full text

Shimada, I., Griffin, J.A. \& Gordus, A., 2000. The technology, iconography and social significance of metals. A multi-dimensional analysis of Middle Sicán objects, in Precolumbian Gold. Technology, style and iconography, ed. McEwan, C.. London: Fitzroy Dearborn, 28-61.Google Scholar@cam-find full text

Spielmann, K.A., 1998. Ritual craft specialists in middle range societies, in Craft and Social Identity, eds Costin, C.L. \& Wright, R... Arlington (VA): American Anthropological

Association, 153-60.Google Scholar@cam - find full text

Spiridonov, E. \& Yanakieva, D., 2009. Modern mineralogy of gold: overview and new data. ArcheoSciences 33, 67-73.CrossRefGoogle Scholar@cam - find full text

Stovel, E., 2001. Patrones funerarios de San Pedro de Atacama y el problema de la presencia de los contextos Tiwanaku [Funerary ritual in San Pedro de Atacama: Evidence for Tiwanaku interment?]. Boletín de Arqueología PUCP (5), 375-95.Google Scholar@cam - find full text

Stovel, E., 2008. Interaction and social fields in San Pedro de Atacama, Northern Chile, in Handbook of South American Archaeology, eds Silverman, H. \& Isbell, W.. New York (NY): Springer, 979-1002.CrossRefGoogle Scholar@cam - find full text

Stovel, E., 2013. Prehistoric atacameño ceramic styles and chronology reassessed. Chungará (Arica) 45(3), 371-85.CrossRefGoogle Scholar@cam - find full text

Tamblay, J., 2004. El Cementerio Larache, los metales y la estratificación social durante el horizonte Tiwanaku en San Pedro de Atacama [The Larache cemetery, metals and social stratification during the Tiwanaku horizon in San Pedro de Atacama], in Tiwanaku:

Aproximaciones a Sus Contextos Históricos y Sociales [Tiwanaku: Approaches to its historical and 
social contexts], eds Rivera, M. \& Kolata, A.. Santiago: Universidad Bolivariana, 37-73.Google Scholar@cam - find full text

Tarragó, M., González, L.R., Ávalos, G. \& Lamamí, M., 2010. Oro de los señores. La tumba 11 de la Isla de Tilcara (Jujuy, noroeste Argentino) [The lords' gold. Tomb 11 of the Island of Tilcara (Jujuy, northwestern Argentina)]. Boletín del Museo Chileno de Arte Precolombino 15(2), 4763.CrossRefGoogle Scholar@am - find full text

Téllez, F. \& Murphy, M., 2007. El cementerio Casa Parroquial; un rescate afortunado. San Pedro de Atacama, Chile [The Casa Parroquial cemetery: A lucky rescue. San Pedro de Atacama, Chile], in Metalurgia en la América antigua. Teoría, arqueología, simbología y tecnología de los metales prehispánicos [Metallurgy in ancient America. Theory, archaeology, symbolismand technology of prehispanic metals], ed. Lleras, R.. Bogotá: Fundación de Investigaciones Arqueológicas Nacionales/Banco de la República de Colombia/Instituto Francés de Estudios Andinos, 5382.CrossRefGoogle Scholar@cam - find full text

Thomas, C., Benavente, A. \& Massone, C., 1985. Algunos efectos de Tiwanaku en la cultura de San Pedro de Atacama [Some effects of Tiwanaku in the culture of San Pedro de Atacama]. Dialogo Andino 4, 259-75.Google Scholar@eam - find full text

Torres-Rouff, C., Knudson, K.J., Pestle, W.J. \& Stovel, E., 2015. Tiwanaku influence and social inequality: a bioarchaeological, biogeochemical, and contextual analysis of the Larache cemetery, San Pedro de Atacama, Northern Chile. American Journal of Physical

Anthropology 158(4), 592-606.CrossRefGoogle Scholar@cam - find full text

Townley, B.K., Hérail, G., Maksaev, V., et al. , 2003. Gold grain morphology and composition as an exploration tool: application to gold exploration in covered areas. Geochemistry: Exploration, Environment, Analysis 3(1), 29-38.Google Scholar@cam - find full text

Uribe, M. \& Agüero, C., 2001. Alfarería, textiles y la integración del Norte Grande de Chile a Tiwanaku [Pottery, textiles and the integration of the arid north of Chile to Tiwanaku]. Boletín de Arqueología PUCP 5, 397-426.Google Scholar@cam - find full text

Uribe, M.A. \& Martinón-Torres, M., 2012. Composition, colour and context in Muisca votive metalwork (Colombia, AD 600-1800). Antiquity 86, 772-91.Google Scholar 